\title{
LAND SUBSIDENCE AND PROBLEMS
}

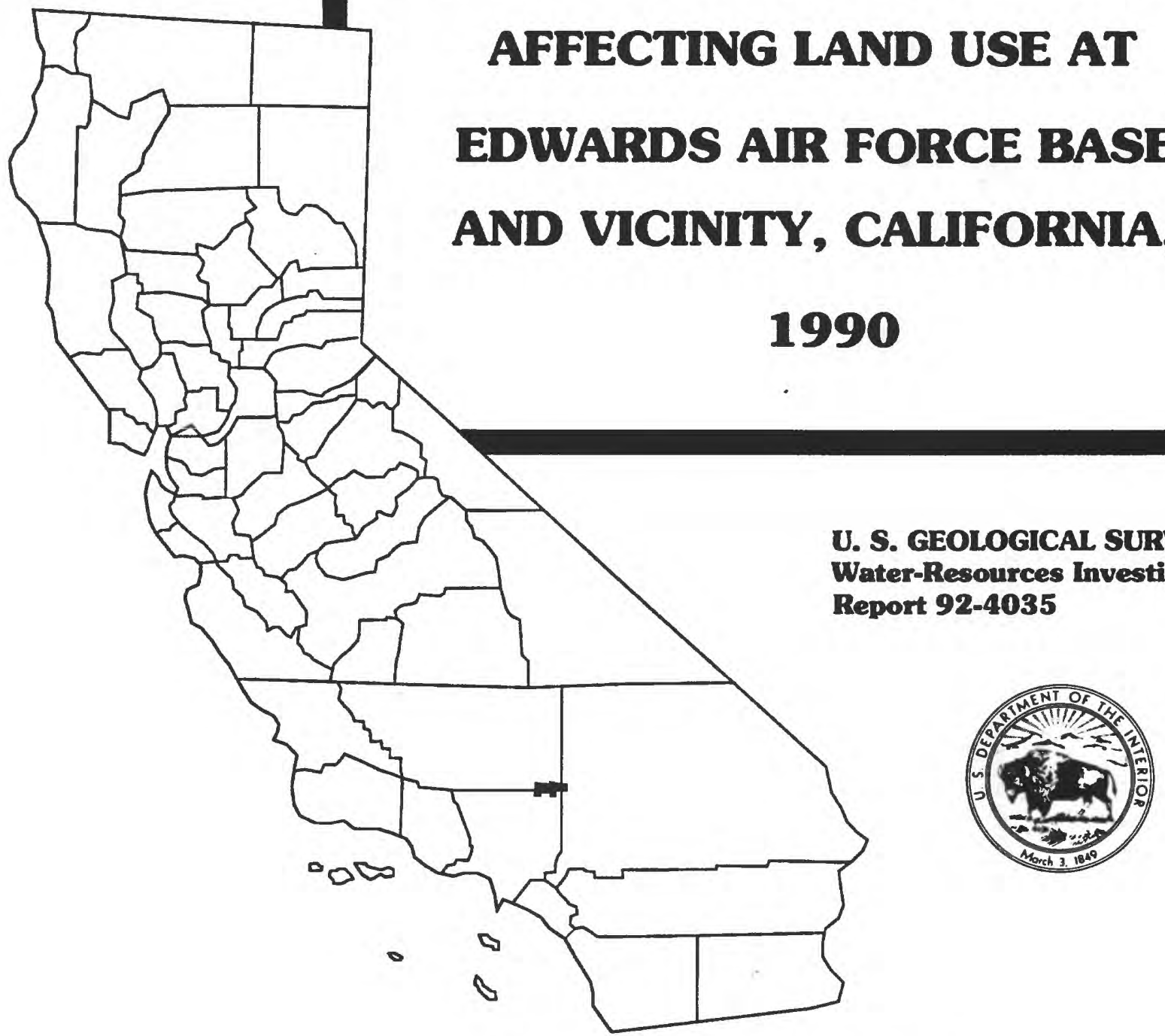

Prepared in cooperation with the U.S. DEPARTMENT OF THE AIR FORCE 


\section{LAND SUBSIDENCE AND PROBLEMS AFFECTING LAND USE AT EDWARDS AIR FORCE BASE AND VICINITY, CALIFORNIA, 1990}

By James C. Blodgett and J.S. Williams

U.S. GEOLOGICAL SURVEY

Water-Resources Investigations Report 92-4035

Prepared in cooperation with the

U.S. DEPARTMENT OF THE AIR FORCE

$\frac{a}{\frac{d}{N}}$ 


\section{U.S. DEPARTMENT OF THE INTERIOR \\ MANUEL LUJAN, JR., Secretary}

\section{U.S. GEOLOGICAL SURVEY \\ Dallas L. Peck, Director}

Any use of trade, product, or firm names in this publication is for descriptive purposes only and does not imply endorsement by the U.S. Government.

For sale by the Books and Open-File Reports Section U.S. Geological Survey Federal Center, Box 25425

Denver, CO 80225

For additional information write to:

District Chief

U.S. Geological Survey

Federal Building, Room W-2233

2800 Cottage Way

Sacramento, CA 95825 


\title{
CONTENTS
}

\author{
Abstract 1 \\ Introduction 1 \\ Description of study area 3 \\ Measurement of land subsidence 4 \\ Global Positioning System surveys 4 \\ Differential leveling surveys $\mathbf{5}$ \\ Magnitude and areal extent of land subsidence 11 \\ Extensometer installation 12 \\ Land-surface profiles 14 \\ Rates of land subsidence 14 \\ Land subsidence and associated problems affecting land use $\mathbf{1 6}$ \\ Fissuring 18 \\ Sinklike depressions 22 \\ Lakebed erosion 23 \\ Summary 24 \\ References cited 25
}

\section{FIGURES}

1. Map showing location of Edwards Air Force Base 2

2. Photograph showing fissure across Runway 25 on Rogers lakebed after January 1991 flooding 3

3. Graph showing relation of ellipsoidal, geoidal, and land-surface heights 4

4-6. Maps showing:

4. Global Positioning System survey control network, March 19896

5. Location of well fields, newly observed fissure, and selected bench marks 7

6. Subsidence (1961-91) at selected bench marks 8

7. Graph showing ground-water-level decline, 1947-89, well 9N/10W-12R1S, South Base well field 11

8. Photograph of bench mark 33MDC showing near-surface land subsidence that has caused exposure of the bench-mark stem 12

9,10. Photographs showing:

9. Holly extensometer site, looking east $\mathbf{1 2}$

10. Holly extensometer 12

11. Graph showing aquifer compaction and water-level change between May 1990 and October 1991 at the Holly extensometer site 13

12. Map showing location of land-surface survey transects A, B, and C $\mathbf{1 5}$

13-15. Profiles of:

13. Land-surface elevation, transect A, Lancaster Boulevard $\mathbf{1 6}$

14. Land-surface elevation, transect $B$, Avenue B 17

15. Land-surface elevation, transect $\mathrm{C}$, Rogers lakebed $\mathbf{1 8}$

16. Photograph showing drainage channels caused by erosion during flooding of Rogers lakebed 19

17. Graph showing land subsidence at bench mark M1155 near South Track well field, 1961-89 19

18. Photograph showing erosion of Rogers lakebed caused by movement of ponded water to fissure opening, March 199120 
19,20. Photographs showing:

19. Small sinklike depression on Rogers lakebed showing small flat, sun-baked polygons on depression wall 20

20. Aerial view of Rogers lakebed showing giant desiccation polygon cracks 21

21. Graph showing land-surface profile at new fissure on Rogers lakebed 22

22,23. Photographs showing:

22. Expanding sinklike depression on Rogers lakebed caused by erosion during periods of lakebed flooding 23

23. Oblique aerial photograph of Rogers lakebed east of South Base well field 24

\section{TABLES}

1. Global Positioning System (GPS) bench marks, GPS and differential leveling survey elevations, and difference between 1961 and 1989-91 surveys 9

2. Bench-mark elevations and difference between 1961 and 1989-91 surveys $\mathbf{1 0}$

3. Results of 1989-91 differential leveling surveys and 1989 Global Positioning System (GPS) surveys 11

\section{Conversion Factors and Vertical Datum}

\section{Conversion Factors}

\begin{tabular}{rcl}
\hline Multiply & By & To obtain \\
\hline foot $(\mathrm{ft})$ & 0.3048 & meter \\
foot per year $(\mathrm{ft} / \mathrm{yr})$ & 0.3048 & meter per year \\
inch (in.) & 25.4 & millimeter \\
mile $(\mathrm{mi})$ & 1.609 & kilometer \\
square mile $\left(\mathrm{mi}^{2}\right)$ & 2.590 & square kilometer \\
\hline
\end{tabular}

\section{Vertical Datum}

Sea level: In this report "sea level" refers to the National Geodetic Vertical Datum of 1929--a geodetic datum derived from a general adjustment of the first-order level nets of the United States and Canada, formerly called Sea Level Datum of 1929. 


\title{
LAND SUBSIDENCE AND PROBLEMS AFFECTING
}

\section{LAND USE AT EDWARDS AIR FORCE BASE AND VICINITY,}

\section{CALIFORNIA, 1990}

\author{
By James C. Blodgett and J.S. Williams
}

\begin{abstract}
Land subsidence in Antelope Valley, which includes Edwards Air Force Base, was first reported in the 1950's; by 1967, about 200 square miles of Antelope Valley were affected by as much as 2 feet of subsidence. Prior to 1973, subsidence on the base was not considered significant. To determine the significance of current land subsidence conditions at Edwards Air Force Base and vicinity, a verticalcontrol network with 41 bench marks was surveyed in 1989 using the Global Positioning System. This network was developed to provide an areawide basis for comparing historic changes in bench-mark elevation on the basis of selected stable bench marks. Accuracy of the ellipsoidal height for the surveyed area, based on North American Datum 1983 (NAD 83), relative to sea level, is about 0.1 foot. Four bench marks that were unaffected by subsidence and with known geoidal heights were used in adjusting the Global Positioning System surveys to sea-level datum.
\end{abstract}

Differential levels to third-order standards of accuracy were surveyed for 65 bench marks in 1989-91 to determine the areal distribution of subsidence. Measured land subsidence ranged from 3.3 feet along the southern edge of Edwards Air Force Base to about 0.3 foot on the northern edge. A gradual decline of ground-water levels, more than 90 feet at some wells since 1947, is associated with the land subsidence. The amount of land subsidence at the base varies depending on the relative quantities of water pumped from various well fields and the differences in geologic substrata. This is shown by varying amounts of subsidence near the western edge of Rogers Lake. Near the southern edge of Rogers Lake, the land subsided more than 2 feet between 1961 and 1989. The average rate of land subsidence near the south end of Rogers lakebed is about 0.1 foot per year.

Land subsidence is causing surface deformation at Edwards Air Force Base and surrounding areas. This deformation has caused the formation of sinklike depressions, fissures, and cracks on Rogers lakebed. These changes adversely affect the use of the lakebed as a runway for airplanes and space shuttles. Repairs to the lakebed have been unsatisfactory because the load-carrying capacity of the repaired lakebed is less than that of the original lakebed. Continued active surface deformation further adversely affects repairs that are made to the runways.

Fissures are a major concern because they may extend to the water table, allowing direct access for contamination by toxic materials. In addition, existing sinklike depressions, fissures, and cracks on the lakebed may not be detected until aircraft or space shuttles exceed the load capacity of the soil. When the lakebed floods, as during periods of flooding in January and March 1991, the sinklike depressions and fissures become avenues of vertical water movement. Changes in lakebed slope and continued land subsidence contribute to the formation of new drainage channels on the lakebed. These channels, which form patterns collectively called desert flowers, increase in size and density following periods of precipitation or lakebed flooding.

\section{INTRODUCTION}

Land subsidence is a long-term phenomenon in the Antelope Valley area of California (Poland, 1984, p. 6-7; Holzer, 1986, p. 748). In 1988, land subsidence was noted at Edwards Air Force Base (AFB) (fig. 1). In the Antelope Valley, subsidence is attributed to compaction of fine-grained materials in the aquifer system that are dewatered because of groundwater pumping. Aseismic (nonearthquake) deformation of the land surface, which appears in the form of sinklike depressions, fissures, and cracks, is commonly associated with regional land subsidence. Some of these surface deformations on Rogers lakebed result in formation of drainage channels along the trace of the fissures (fig. 2). Changes on the lakebed adversely affect the use of the lakebed surface for landing airplanes and space shuttles. 


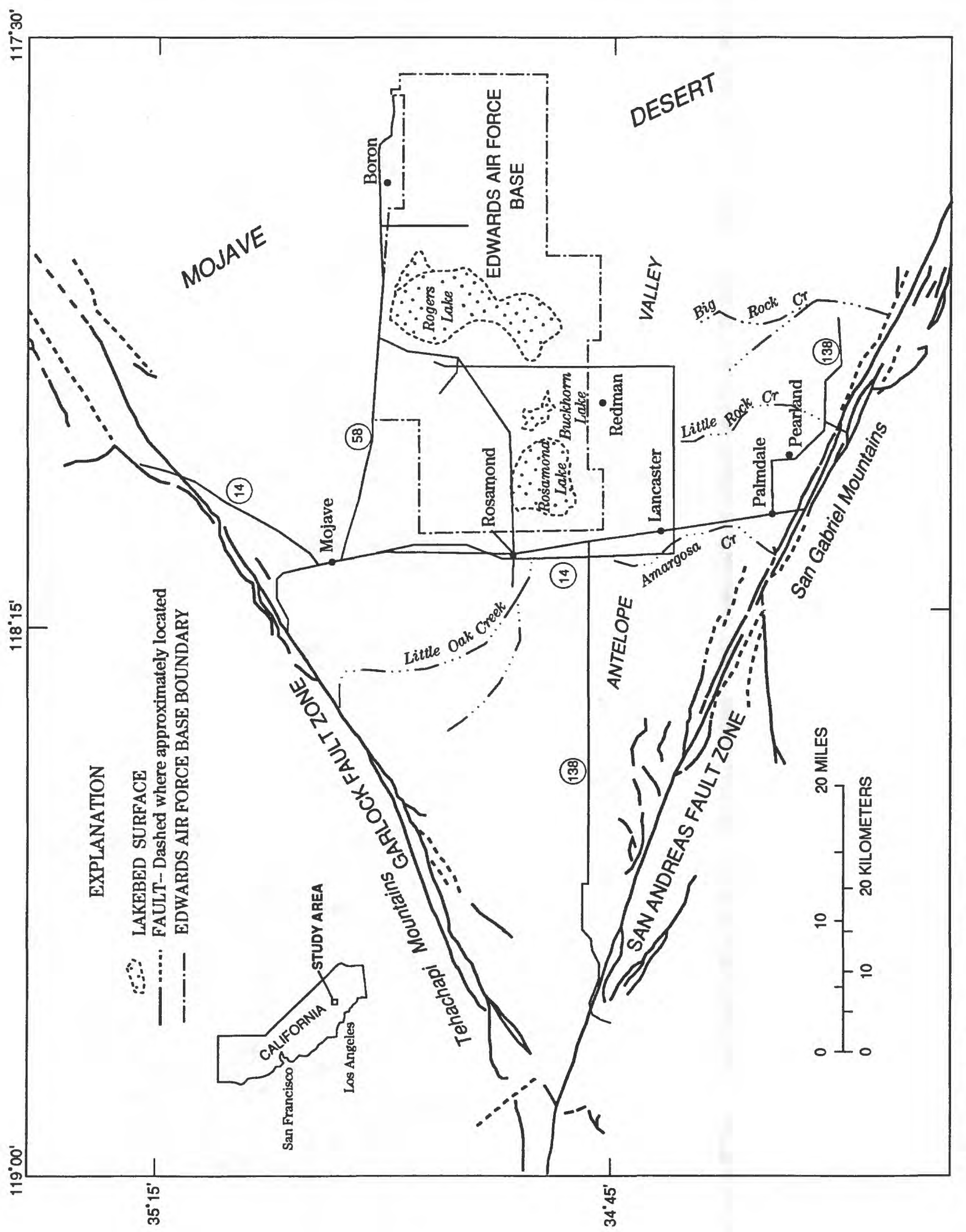

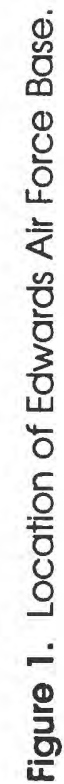




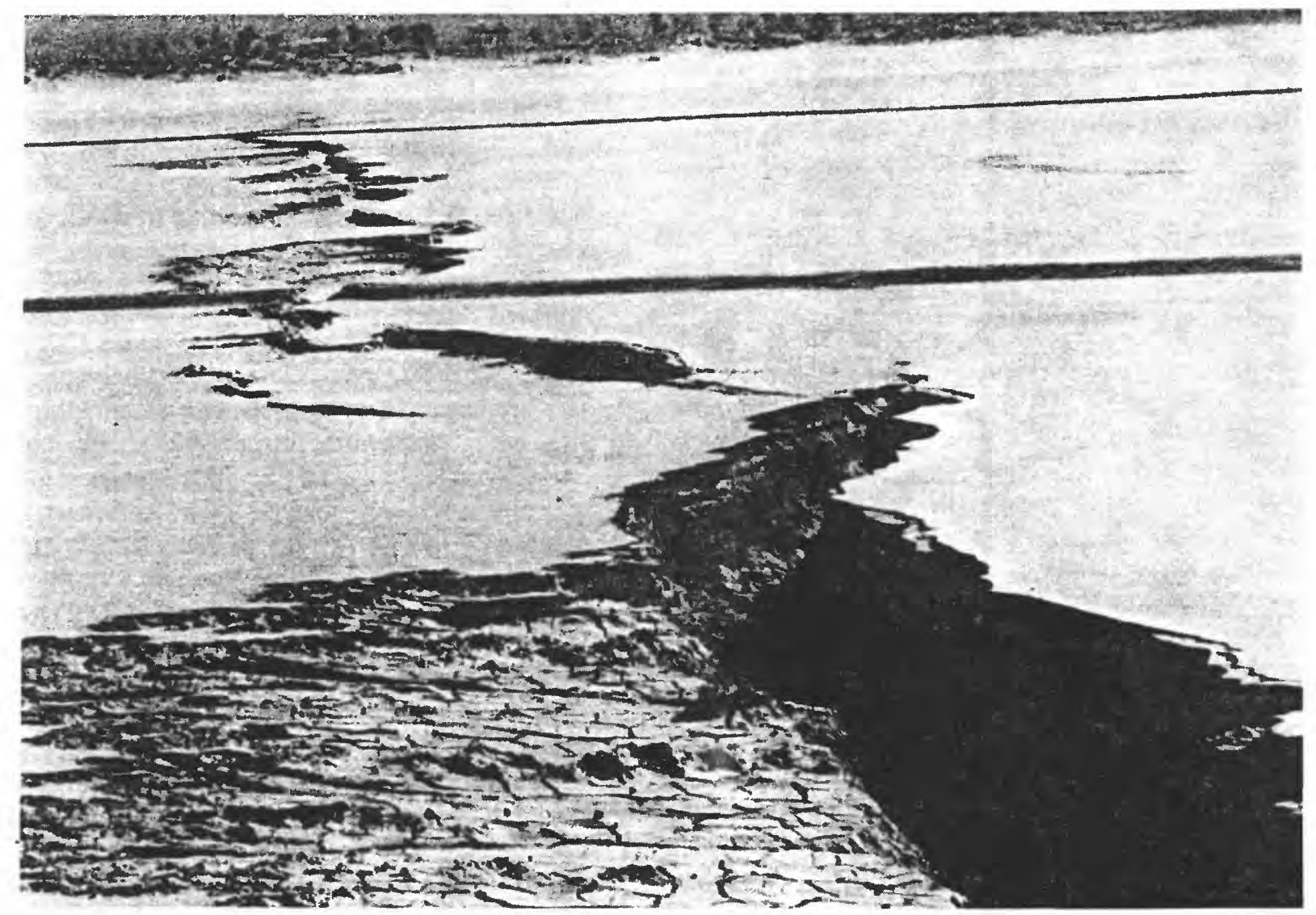

Figure 2. Fissure across Runway 25 on Rogers lakebed after January 1991 flooding. This fissure also is a drainage channel and point of infiltration to ground water. Note cracks that form small polygons on eroded area near fissure. Width of fissure at land surface is as much as 10 feet. Photograph courtesy of U.S. Air Force, February 1991.

Expenditures to date (1990) for runway repair have been high, and the repairs have been somewhat ineffective (Melvin Marmet, U.S. Air Force, oral commun., July 1991). The load-carrying capacity of the repaired lakebed is less than that of the original lakebed, and active deformation continues to adversely affect the repairs. Evidence of new sinklike depressions and fissures indicates that the lakebed is being subjected to continuing land-surface deformation.

The purpose of this report is to present the results to date of recent studies done by the U.S. Geological Survey, in cooperation with the U.S. Department of the Air Force, to determine the cause and areal extent of land subsidence and surface deformation on Rogers lakebed and vicinity, and the effects of surface deformation on runways used for aircraft landings at Edwards AFB in southern California. Because of the time-related effects of land subsidence, several years of data collection will be needed to establish subsidence trends and evaluate those factors causing land subsidence. Land subsidence was noted previously near Lancaster, which is near the base (Lofgren, 1966; Lewis and Miller, 1968; Poland, 1984, p. 6-7). Thus, selected off-base sites were included for data collection and analysis to determine if land subsidence is continuing near the base and if near-base ground-water pumping may be contributing to land subsidence and surface deformation on the base.

\section{DESCRIPTION OF STUDY AREA}

Antelope Valley, about $60 \mathrm{mi}$ north of Los Angeles, California in the northwestern part of the Mojave Desert (fig. 1), has an arid environment. Historically, water supplies have been obtained primarily by pumping ground water. The valley is a 
closed, inland drainage basin covering about 2,400 $\mathrm{mi}^{2}$. The Tehachapi Mountains, with elevations to $8,000 \mathrm{ft}$ above sea level, form the northwestern border; the San Gabriel Mountains, with elevations to $10,000 \mathrm{ft}$, form the southwestern border. Average elevation of the valley floor is about $2,500 \mathrm{ft}$. Mean annual precipitation at Palmdale on the valley floor, based on records between 1933 and 1989, is 7.5 inches. The Tehachapi and San Gabriel Mountains are barriers against the prevailing west-to-east movement of storms from the Pacific Ocean. As a result, the quantity of precipitation in Antelope Valley shows a rainshadow effect; average annual precipitation ranges from 25.6 inches in the west part of Antelope Valley to 4.8 inches at Edwards AFB near Rogers Lake. Most streamflow occurs during the winter months, November through March. Runoff from uplands enters the valley floor through various creeks, and excess flows follow unpredictable paths across the valley floor toward Rogers, Buckhorn, and Rosamond Lakes (fig. 1).

The aquifer system in Antelope Valley was described by Durbin (1978) as a ground-water basin with a surface area of $900 \mathrm{mi}^{2}$ and a thickness of as much as $5,000 \mathrm{ft}$ beneath the valley floor. The ground-water system consists of two alluvial aquifers separated by fine-grained lacustrine deposits. Runoff from the Tehachapi and San Gabriel Mountains serves as the principal sources of ground-water basin recharge.

Historically, water supplies for the valley have been obtained primarily by pumping ground water. During 1922-90, ground-water pumping in excess of natural recharge has resulted in a steady decline of the ground-water level in the basin. Beds of silt and clay material (lacustrine deposits) that are subject to compaction when dewatered are interspersed throughout the alluvial aquifer system in the valley. Poland (1984, p. 10) indicated that the range of depth of these beds is between 200 and 1,000 ft. Land subsidence is associated with declining ground-water levels caused by pumping and the presence of beds of finegrained (lacustrine) material that are subject to compaction.

\section{MEASUREMENT OF LAND SUBSIDENCE}

Land subsidence in Antelope Valley was first reported by Lewis and Miller (1968) after several differential leveling survey lines through Rosamond, Palmdale, and Redman (fig. 1) were compared.
Between 1955 and 1967, about $200 \mathrm{mi}^{2}$ in Antelope Valley were affected by land subsidence, with subsidence of $1.8 \mathrm{ft}$ in Lancaster (fig. 1) and more than $2 \mathrm{ft}$ in two areas 6 to 10 mi east of Lancaster.

\section{GLOBAL POSITIONING SYSTEM SURVEYS}

Global Positioning System (GPS) surveys were used to establish vertical-control data at Edwards AFB and vicinity in March 1989. GPS, described by Collins (1989), is a U.S. Department of Defense satellite-based navigation system designed to provide worldwide positioning capability. Field equipment consisted of an antenna and a receiver-processor unit, which also records data on a cassette tape. Precise relative positions of two or more bench marks are determined from satellite-tracking data received simultaneously at each bench mark.

Elevations for selected bench marks were computed by calculating the separation (distance $N$, fig. 3 ) of GPS ellipsoidal heights from the geoid, which is the equipotential surface coinciding with sea level. The geoidal separation, relative to sea level, ranges from about 59 to $131 \mathrm{ft}$ in the conterminous United States (Collins, 1989). These elevations can then be compared with those from earlier differential leveling surveys to calculate the amount of subsidence to date.

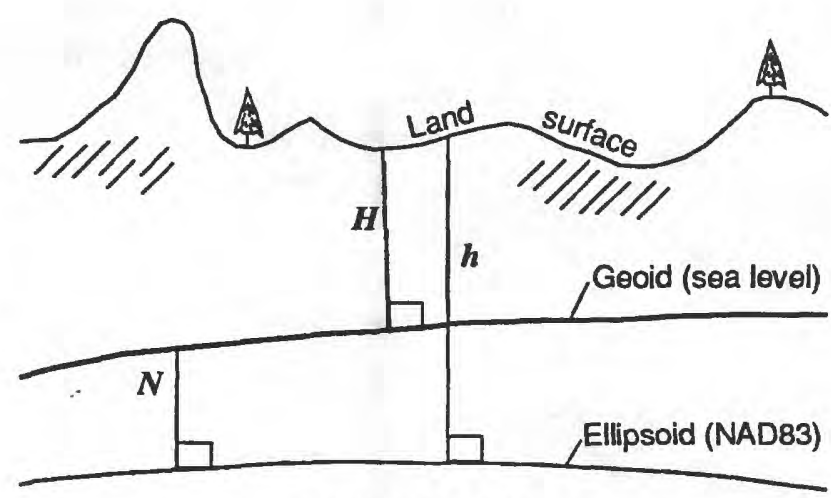

\section{EXPLANATION}

$\boldsymbol{h}$ Ellipsoidal height, referenced to the ellipsoid

$H$ Land-surface elevation, referenced to the geoid, or sea level

$N$ Geoid separation, NAD83-North American Datum 1983

Figure 3. Relation of ellipsoidal, geoidal, and land-surface heights (from Blodgett and others, 1990). 
Bench-mark elevations referenced to sea level cannot be defined by GPS surveys without accurate measurements of the applicable amount of geoidal separation to the study area. Changes in elevation caused by land subsidence, however, are equivalent to changes in ellipsoidal height obtained during successive GPS surveys. Changes in ellipsoidal height can be measured by repeat GPS surveys; accuracy is limited only by the inherent errors in the GPS technique, presently about $1.5 \mathrm{ppm}$ (parts per million) of the distance between bench marks (Bock and others, 1984).

One of the objectives of the GPS surveys at Edwards AFB has been to establish a precise network of bench marks with coordinates defined by GPS to monitor land subsidence through future GPS surveys. The GPS network is designed to include stable bench marks on bedrock and at other locations to reference the network in the horizontal planes ( $x, y$ coordinates) and vertical planes ( $z$ coordinate). For the 1989 GPS survey, bench marks Buckhorn, F1147, and Y1139 on bedrock and bench mark 6MDC, which is about $7 \mathrm{mi}$ from pumped wells within the project area, were used as stable sites (fig. 4). In the course of GPS surveying, precise horizontal coordinates also have been determined for all bench marks.

The selection of bench marks included in the GPS survey was based on one or more of the following criteria:

- Bench marks were referenced for a long period of time by differential level surveys.

- Some bench marks are on bedrock to use as reference sites.

- Bench marks are in areas of suspected subsidence.

- Visibility of the satellites from the bench marks is unobstructed. At some locations, alternative (offset) bench marks were installed.

The GPS-network design for the survey of Edwards AFB includes 41 bench marks (fig. 4, table 1), including stable bench marks on the periphery of the project area and bench marks in areas affected by land subsidence within the project area. GPS measurements were obtained at selected bench marks that recently had been surveyed in order to calculate the geoidal separation. GPS observations were obtained from at least four satellites for a period of 4 hours and 50 minutes at each bench mark. The GPS data are of excellent quality, except those collected on March 14, 1989, when an extreme solar flare caused a considerable amount of ionospheric noise.

Processing and analysis of the GPS data were completed using the broadcast ephemeris. The computed vectors between bench marks and the satellites are combined in a least-squares adjustment using weights that are the standard errors (typically $0.02 \mathrm{ft}$ in each component) estimated in the PHASAR vector computations. The vectors then were adjusted holding bench mark Buckhorn fixed in all three components and bench marks F1147, Y1139, and $6 \mathrm{MDC}$ fixed in their ellipsoidal heights (fig. 4). These bench marks were selected because consistent elevations for these bench marks are known. The Rapp 360 geopotential model (Rapp and Cruz, 1986) was used to adjust the published elevations to obtain the geoid heights. For this adjustment, the survey network was rotated along the $x$ and $y$ axes. This fit the GPS system with a network of local coordinates that are based on published elevations of bench marks Buckhorn, F1147, Y1139, and 6MDC. As a final step, the geoid heights obtained from this adjustment for geoid separation were corrected to give the best estimate of current bench-mark elevations in the network.

\section{DIFFERENTIAL LEVELING SURVEYS}

Differential (conventional) leveling surveys between selected bench marks during 1989-91, plus those included in the 1989 GPS surveys were used to determine the magnitude, areal extent, and approximate rates of land subsidence at Edwards $\mathrm{AFB}$ and vicinity. Differential leveling surveys to various bench marks in the survey area (figs. 5 and 6, tables 1 and 2) were of first-, second-, or third-order standards of accuracy, as defined by the National Oceanic and Atmospheric Administration (1980). Although first- or second-order-accuracy surveys were done in 1926, 1947, 1955, 1961, 1965, and 1973, most of the recent surveys are of third-order or better accuracy (1989-91) or were derived from GPS surveys (1989). These were done to establish a recent vertical-control network for the study area. 


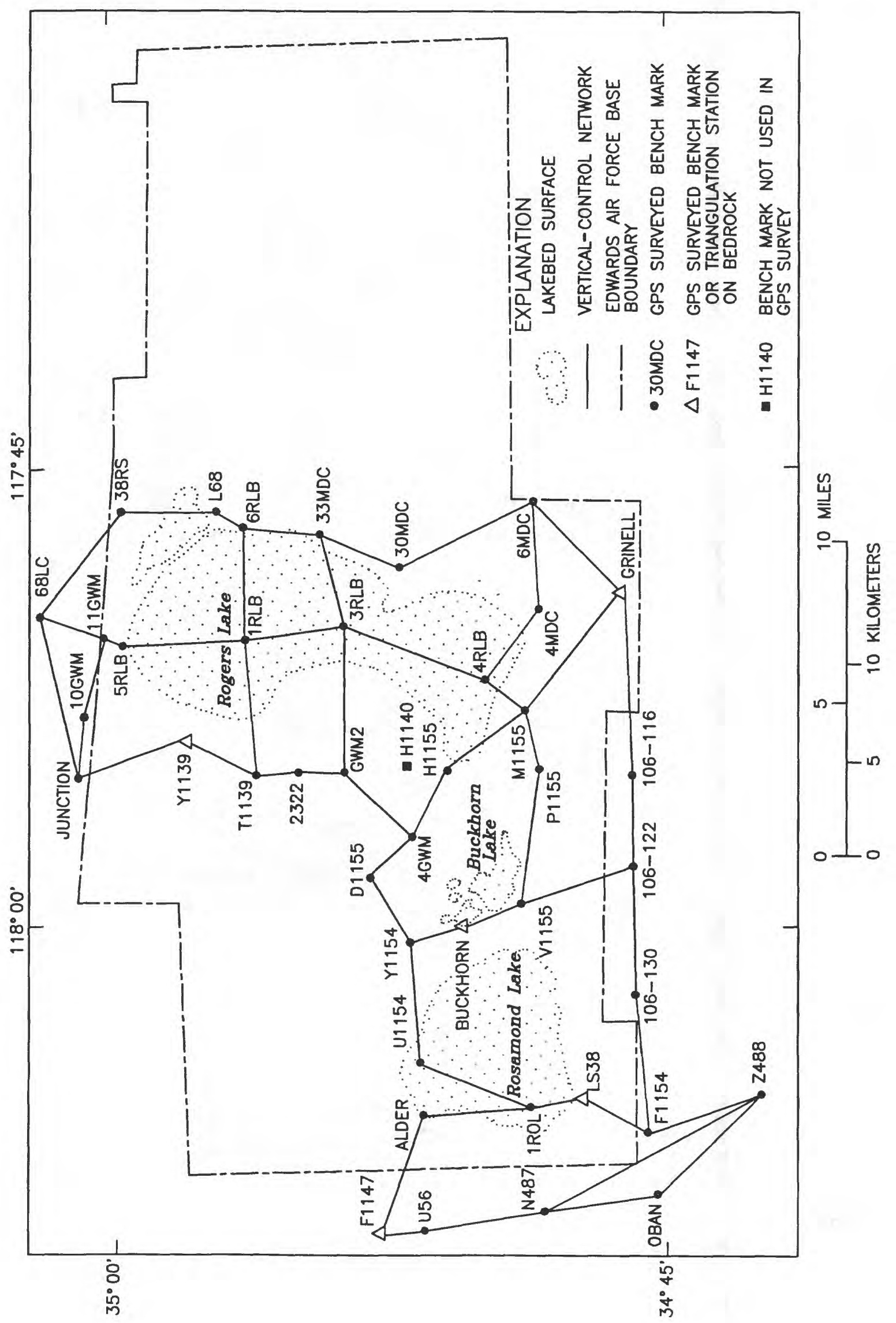

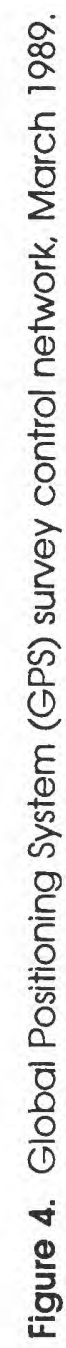




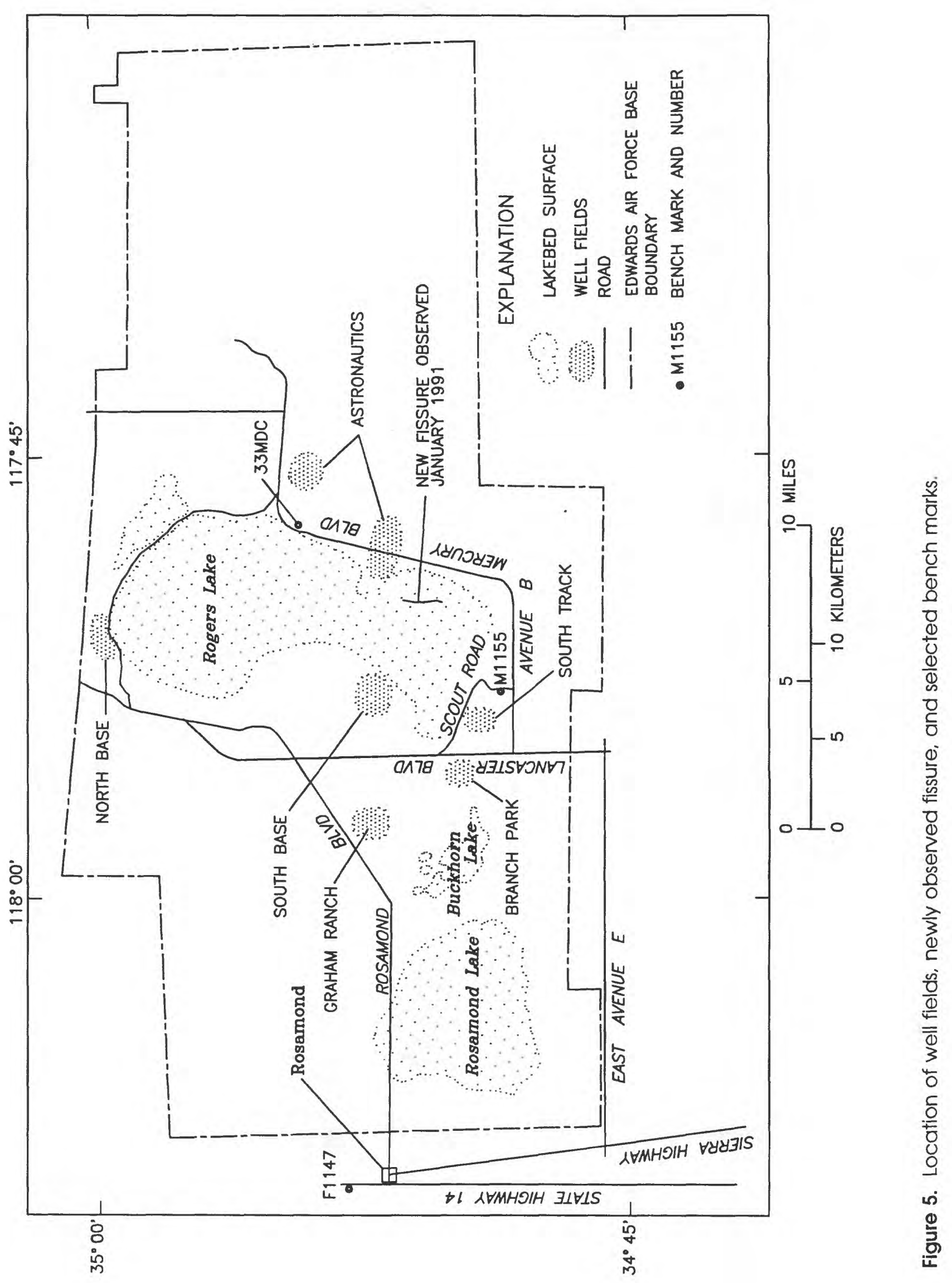




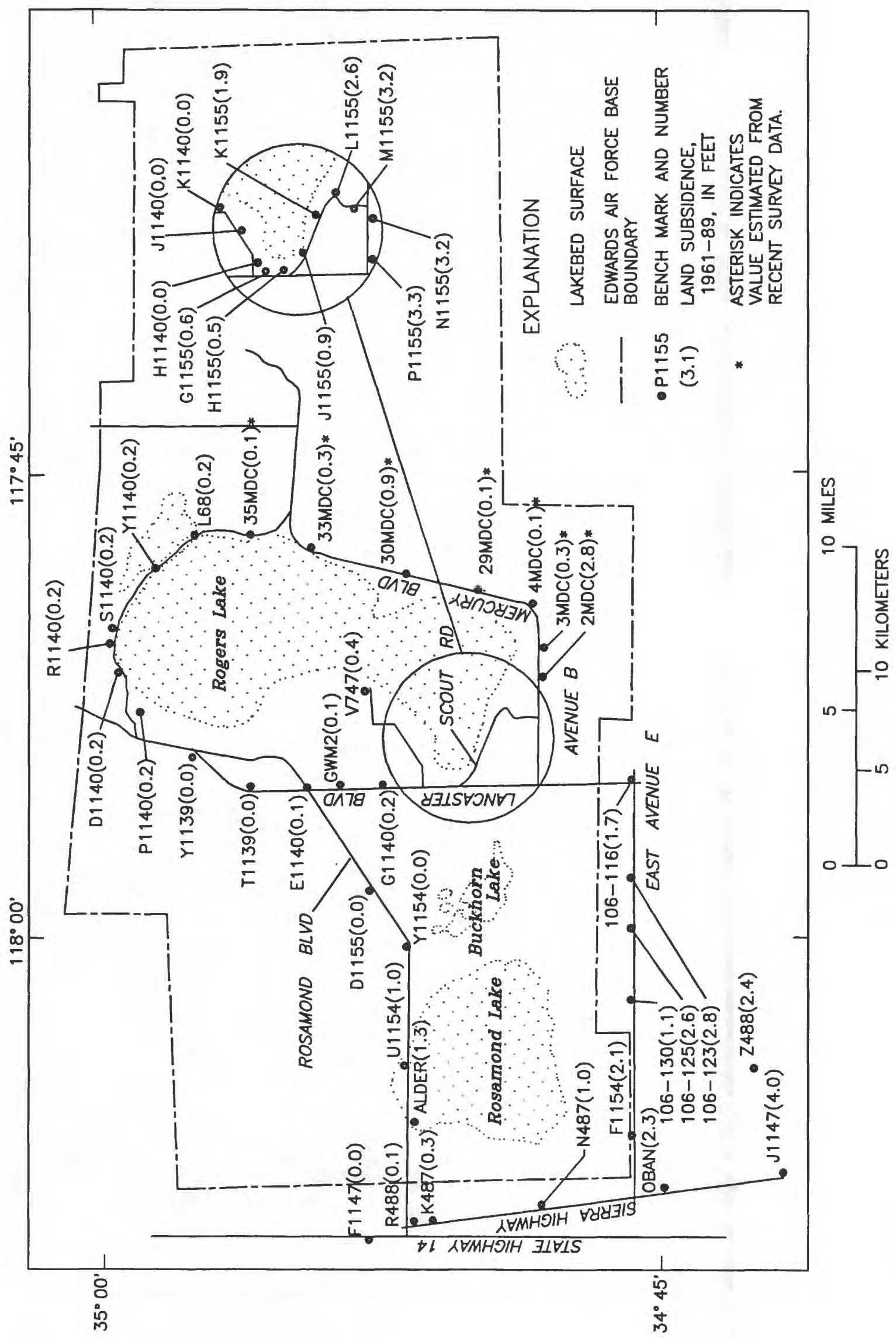

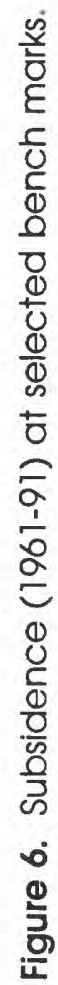


Table 1. Global Positioning System (GPS) bench marks, GPS and differential leveling survey elevations, and difference between 1961 and 1989-91 surveys

[NGS, 1961: First or second order surveys by National Geodetic Survey. USGS, 1973: First or second order surveys by U.S. Geological Survey. USGS, 1989-91: Third order surveys by U.S. Geological Survey. --, no data; nc, not calculated]

\begin{tabular}{|c|c|c|c|c|c|}
\hline \multirow[b]{2}{*}{$\begin{array}{c}\text { GPS } \\
\text { bench mark }\end{array}$} & \multicolumn{5}{|c|}{ Elevation, in feet above sea level } \\
\hline & $\begin{array}{l}\text { NGS } \\
1961\end{array}$ & $\begin{array}{c}\text { USGS } \\
1973\end{array}$ & $\begin{array}{l}\text { GPS survey } \\
\text { March } 1989\end{array}$ & $\begin{array}{c}\text { USGS } \\
1989-91\end{array}$ & $\begin{array}{c}\text { Difference } \\
\text { between } 1961 \\
\text { and } 1989-91\end{array}$ \\
\hline $\mathrm{F} 1147^{1}$ & $2,447.32$ & $2,447.32$ & $2,447.32$ & -- & 0 \\
\hline U56 & $2,325.96$ & $2,325.88$ & $2,325.82$ & -- & .1 \\
\hline N487 & $2,305.99$ & $2,305.28$ & $2,305.04$ & -- & 1 \\
\hline OBAN & $2,305.19$ & $2,303.51$ & $2,302.92$ & -- & 2.3 \\
\hline Z488 & $2,364.57$ & -- & $2,362.17$ & -- & 2.4 \\
\hline ALDER & $2,275.96$ & $2,275.25$ & $2,274.63$ & -- & 1.3 \\
\hline U1154 & $2,274.98$ & $2,274.28$ & $2,273.98$ & -- & 1 \\
\hline IROL & -- & -- & $2,273.31$ & -- & $\mathrm{nc}$ \\
\hline F1154 & $2,303.45$ & $2,302.57$ & $2,301.31$ & -- & 2.1 \\
\hline $106-130$ & $2,318.85$ & $2,318.44$ & $2,317.71$ & -- & 1.1 \\
\hline $106-122$ & $2,343.64$ & $2,342.27$ & $2,340.60$ & -- & 3 \\
\hline $106-116$ & $2,358.14$ & $2,357.34$ & $2,356.46$ & -- & 1.7 \\
\hline GRINELL & -- & -- & $3,174.17$ & -- & $\mathrm{nc}$ \\
\hline V1155 & $2,298.76$ & - & $2,296.12$ & -- & 2.6 \\
\hline BUCKHORN & -- & $2,401.01$ & $2,401.01$ & -- & $\mathrm{nc}$ \\
\hline Y1154 & $2,408.36$ & $2,408.23$ & $2,408.39$ & -- & 0 \\
\hline D1155 & $2,378.07$ & $2,377.90$ & $2,378.05$ & -- & 0 \\
\hline 4GWM & -- & $2,322.69$ & $2,322.37$ & -- & nc \\
\hline H1155 & $2,280.64$ & $2,280.34$ & $2,279.94$ & -- & .7 \\
\hline M1155 & $2,300.82$ & $2,299.57$ & $2,297.63$ & $2,297.66$ & 3.2 \\
\hline P1155 & $2,311.64$ & $2,310.40$ & $2,308.53$ & $2,308.35$ & 3.3 \\
\hline $4 \mathrm{MDC}$ & -- & $2,332.29$ & $2,332.15$ & $2,332.15$ & $\mathrm{nc}$ \\
\hline $6 \mathrm{MDC}$ & -- & $2,602.38$ & $2,602.39$ & -- & nc \\
\hline GWM2 & $2,302.24$ & $2,302.09$ & $2,302.10$ & -- & .1 \\
\hline 3RLB & -- & -- & $2,271.75$ & -- & $\mathrm{nc}$ \\
\hline $30 \mathrm{MDC}^{2}$ & $2,292.45$ & $2,291.89$ & $2,291.40$ & $2,291.52$ & .9 \\
\hline $33 \mathrm{MDC}^{2}$ & $2,278.93$ & $2,278.87$ & $2,278.67$ & $2,278.64$ & .3 \\
\hline 2322 & -- & -- & $2,321.32$ & -- & nc \\
\hline T1139 & $2,448.68$ & $2,448.53$ & $2,448.78$ & -- & nc \\
\hline$Y 1139^{3}$ & $2,369.54$ & $2,369.54$ & $2,369.68$ & $2,369.54$ & 0 \\
\hline $1 R L B$ & -- & -- & $2,270.80$ & -- & nc \\
\hline 6RLB & -- & -- & $2,280.05$ & $2,279.99$ & nc \\
\hline L68 & $2,282.45$ & $2,282.22$ & $2,282.08$ & $2,282.15$ & .3 \\
\hline $5 R L B$ & -- & -- & $2,274.21$ & $2,274.21$ & $\mathrm{nc}$ \\
\hline 10GWM & -- & $2,327.43$ & $2,327.29$ & -- & $\mathrm{nc}$ \\
\hline GWM11 & -- & $2,283.10$ & $2,282.98$ & -- & $\mathrm{nc}$ \\
\hline JUNCTION & -- & $2,375.58$ & $2,375.65$ & -- & $\mathrm{nc}$ \\
\hline $68 \mathrm{LC}$ & -- & $2,330.20$ & $2,330.17$ & -- & $\mathrm{nc}$ \\
\hline 4RLB & -- & -- & $2,269.02$ & -- & $\mathrm{nc}$ \\
\hline 38RS & -- & $2,315.27$ & $2,315.13$ & -. & $\mathrm{nc}$ \\
\hline $\mathrm{LS} 8^{2}$ & $2,284.96$ & -- & $2,283.66$ & - & 1.3 \\
\hline
\end{tabular}

${ }^{1}$ The elevation of this bench mark located on bedrock and determined during surveys by National Geodetic Survey in 1965 was held at $2,447.32 \mathrm{ft}$.

${ }^{2}$ Estimated on basis of $1989-91$ surveys.

${ }^{3}$ The elevation of this bench mark located on bedrock and determined during surveys by U.S. Geological Survey in 1973 was held at $2,369.54 \mathrm{ft}$. 
Table 2. Bench-mark elevations and difference between 1961 and 1989-91 surveys

[NGS, 1961: First or second order surveys by National Geodetic Survey. USGS, 1973: First or second order surveys by U.S. Geological Survey. USGS, 1989-91: Third order surveys by U.S. Geological Survey. --, no data]

\begin{tabular}{|c|c|c|c|c|}
\hline \multirow[b]{2}{*}{ Bench mark } & \multicolumn{4}{|c|}{ Elevation, in feet above sea level } \\
\hline & $\begin{array}{l}\text { NGS } \\
1961\end{array}$ & $\begin{array}{c}\text { USGS } \\
1973\end{array}$ & $\begin{array}{c}\text { USGS } \\
1989-91\end{array}$ & $\begin{array}{c}\text { Difference } \\
\text { between } 1961 \\
\text { and } 1989-91\end{array}$ \\
\hline G1155 & $2,284.99$ & $2,284.67$ & $2,284.38$ & 0.6 \\
\hline M1155 & $2,300.82$ & $2,299.57$ & $2,297.66$ & 3.2 \\
\hline $\mathrm{J} 1140^{1}$ & $2,282.54$ & -- & $2,282.50$ & 0 \\
\hline $\mathrm{K} 1140^{1}$ & $2,284.18$ & -- & $2,284.22$ & 0 \\
\hline $\mathrm{H} 1140^{1,2}$ & $2,325.06$ & -- & $2,325.06$ & 0 \\
\hline G1140 & $2,285.15$ & $2,285.01$ & $2,285.00$ & .2 \\
\hline N1155 & $2,309.33$ & $2,308.27$ & $2,306.08$ & 3.3 \\
\hline $106-125$ & $2,333.78$ & -- & $2,331.15$ & 2.6 \\
\hline $106-123$ & $2,339.09$ & $2,337.78$ & $2,336.29$ & 2.8 \\
\hline V74 $7^{1}$ & $2,280.88$ & -- & $2,280.47$ & .4 \\
\hline R1140 & $2,306.89$ & $2,306.70$ & $2,306.68$ & .2 \\
\hline L1155 & $2,286.48$ & $2,285.48$ & $2,283.89$ & 2.6 \\
\hline K1155 & $2,287.07$ & $2,286.26$ & $2,285.21$ & 1.9 \\
\hline J1155 & $2,277.71$ & $2,277.18$ & $2,276.76$ & 1 \\
\hline $2 \mathrm{MDC}$ & ${ }^{3} 2,298.05$ & $2 ; 296.80$ & $2,295.21$ & 2.8 \\
\hline K487 & $2,313.88$ & -- & $2,313.54$ & .3 \\
\hline R488 & $2,337.79$ & $2,337.69$ & $2,337.66$ & .1 \\
\hline E1140 & $2,320.36$ & $2,320.23$ & $2,320.26$ & .1 \\
\hline $29 \mathrm{MDC}$ & ${ }^{3} 2,295.77$ & $2,295.75$ & $2,295.66$ & .1 \\
\hline $35 \mathrm{MDC}$ & ${ }^{3} 2,279.45$ & $2,279.45$ & $2,279.39$ & .1 \\
\hline $\mathrm{Y} 1140$ & $2,291.60$ & $2,291.39$ & $2,291.37$ & .2 \\
\hline S1140 & $2,309.22$ & $2,309.02$ & $2,309.01$ & .2 \\
\hline D1140 & $2,299.87$ & $2,299.70$ & $2,299.67$ & .2 \\
\hline P1140 & $2,286.23$ & -- & $2,286.05$ & .2 \\
\hline
\end{tabular}

${ }^{1}$ Bench marks on same line surveyed in 1961 and 1990-91. The small discrepancies between 1961 and 1991 elevations are attributed to variations in leveling adjustments because the elevation of bench mark H1140 is held constant.

${ }^{2}$ Bench mark located on bedrock and assumed to be stable for surveys 1961-91.

${ }^{3}$ Values estimated from recent survey data.

A comparison of 1989-91 differential leveling and 1989 GPS survey results for selected bench marks is given in table 3 . The median difference in elevation between the two methods is $0.09 \mathrm{ft}$. The mean elevation difference of about $0.10 \mathrm{ft}$ indicates that the amount of land subsidence estimated using GPS data is accurate to the nearest $\pm 0.1 \mathrm{ft}$ (tables 1 and 2).

All surveys made at the base in 1973 were based on the elevation of bench mark F1147, which was established north of Rosamond in 1961 (fig. 5). This bench mark is on an outcrop of a lightcolored, indurated, tuffaceous rock of Tertiary age, at an elevation of $2,447.318 \mathrm{ft}$ above sea level, (U.S.
Department of Commerce, 1966). It is about $1.2 \mathrm{mi}$ north of Rosamond on the west side of a dirt road that parallels State Highway 14. The stratified, pyroclastic rocks dip gently southwest and lie unconformably above pre-Tertiary quartz monzonite (Dibblee, 1963, p. 156-160) and below Miocene fanglomerate (Dibblee, 1958, p. 141; 1963, p. 187). There is no evidence of recent tectonic movement along any of the major or minor faults in the surrounding area (Dibblee, 1963), indicating that the bedrock at bench mark F1147 is stable. Other bench marks included in the vertical-control network on Edwards AFB that are considered to be on similar stable rock (bedrock) outcrops are Y1139, H1140, Grinell (triangulation station), and Buckhorn (fig. 4). 
Table 3. Results of 1989-91 differential leveling surveys and 1989 Global Positioning System (GPS) surveys

\begin{tabular}{|c|c|c|c|c|}
\hline \multirow[b]{2}{*}{ Bench-mark pairs } & \multirow{2}{*}{$\begin{array}{c}\text { Line } \\
\text { length } \\
\text { (miles) }\end{array}$} & \multicolumn{3}{|c|}{ Elevation difference, in feet above sea level } \\
\hline & & $\begin{array}{c}\text { GPS surveys } \\
1989\end{array}$ & $\begin{array}{l}\text { Differential } \\
\text { leveling } \\
1989-91\end{array}$ & $\begin{array}{c}\text { Summary } \\
\text { difference } \\
\text { (absolute value) }\end{array}$ \\
\hline $106-130$ to $106-122$ offset & 6 & 20.866 & 21.020 & 0.154 \\
\hline H1155 offset to GWM2 & 7.9 & 26.406 & 26.340 & .066 \\
\hline 4MDC to M1155 & 2.8 & 34.514 & 34.577 & .063 \\
\hline H1155 offset to M1155 & 4.4 & 21.944 & 21.906 & .038 \\
\hline F1147 to U56 & 1.7 & 121.490 & 121.506 & .016 \\
\hline $3 R L B$ to $1 R L B$ & 3.2 & .951 & 1.093 & .142 \\
\hline $1 R L B$ to $5 R L B$ & 3.6 & 3.412 & 3.417 & .05 \\
\hline $1 \mathrm{RLB}$ to $6 \mathrm{RLB}$ & 3.4 & 9.252 & 9.260 & .008 \\
\hline $3 R L B$ to $33 \mathrm{MDC}$ & 3.1 & 6.923 & 6.847 & .076 \\
\hline GWM2 to $3 R L B$ & 6.7 & 30.348 & 30.258 & .09 \\
\hline GWM11 offset to 5RLB & .7 & 9.416 & 9.503 & .087 \\
\hline $106-122$ offset to V1155 & 4 & 42.454 & 42.714 & .260 \\
\hline V1155 to BUCKHORN & 2.4 & 104.888 & 104.645 & .243 \\
\hline L68 to $6 \mathrm{RLB}$ & .9 & 2.034 & 2.160 & .126 \\
\hline Median ....... & $\cdots$ & $\ldots \ldots \ldots$ & - & $\ldots 0.09$ \\
\hline Mean ....... & 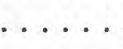 & 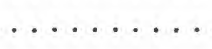 & 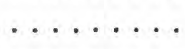 & 0.10 \\
\hline
\end{tabular}

\section{MAGNITUDE AND AREAL EXTENT OF LAND SUBSIDENCE}

A comparison of the results of differential leveling surveys for 1961 and 1989-91 indicates the extent of land subsidence at Edwards AFB and at selected, nearby locations. The greatest amounts of subsidence at the base for 1961-91 are near the South Track well field (figs. 5 and 6) and near the southern border of the base. Land subsidence for 1961-91 ranged from about $0.2 \mathrm{ft}$ in areas near the north end of Rogers Lake to $3.3 \mathrm{ft}$ south of the lake. Subsidence along the east edge of Rogers Lake near the Astronautics well fields is about $0.9 \mathrm{ft}$ (figs. 5 and 6). A general decline in ground-water levels of about 90 $\mathrm{ft}$ since 1947 (fig. 7) is associated with land subsidence on the base.

Bench mark 33MDC (figs. 5 and 8), on the east side of Rogers Lake, shows an interesting subsidence phenomenon. When this bench mark was established in 1973, the brass cap and the top of the 6-inch diameter pipe were placed flush with the land surface. The brass cap presently is about $0.3 \mathrm{ft}$ above the 6inch diameter pipe, which is about $0.1 \mathrm{ft}$ above the land surface. Wind erosion of the soil probably caused the $0.1 \mathrm{ft}$ exposure of the 6-inch diameter

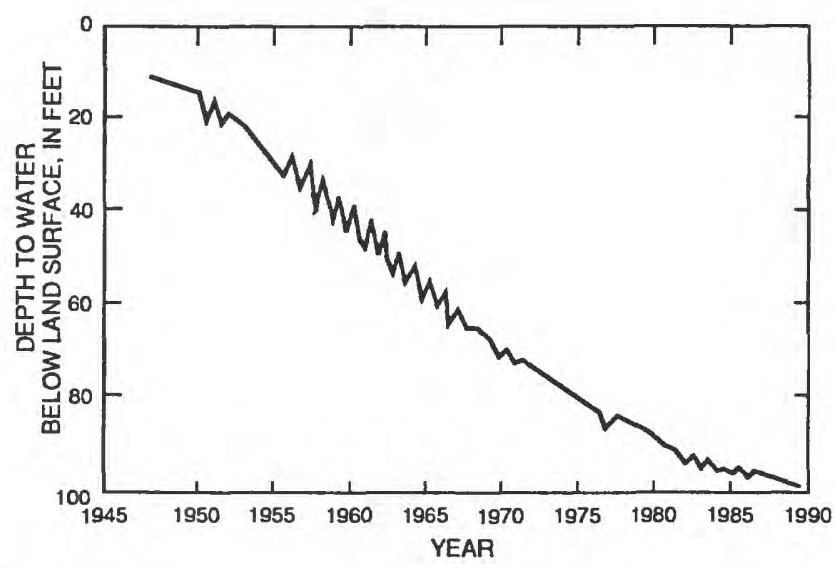

Figure 7. Ground-water-level decline, 1947-89, well 9N/10W-12R1S, South Base well field. Depth of well is about 250 feet.

pipe. The brass cap is $0.3 \mathrm{ft}$ lower in elevation thanin 1973 on the basis of elevations determined from the regional vertical-control network surveyed in 1989-91 (table 1). The depth of the pipestem that supports the brass cap is unknown, but it is likely to be less than $20 \mathrm{ft}$. Therefore, there may be both shallow (depths less than $20 \mathrm{ft}$ ) and deep (depths greater than $20 \mathrm{ft}$ ) subsidence occurring at this site. 


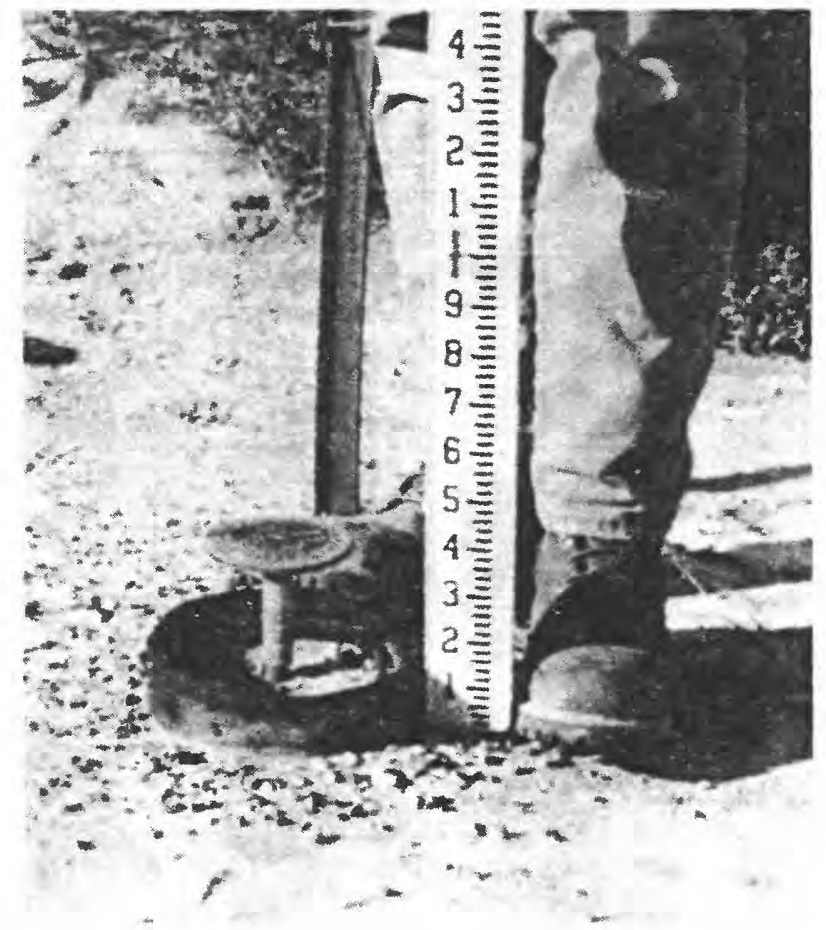

Figure 8. Bench mark 33MDC showing nearsurface land subsidence that has caused exposure of the bench-mark stem. Bench mark, located east of Rogers Lake near Mercury Boulevard, was installed in 1973. Photographed April 1990.

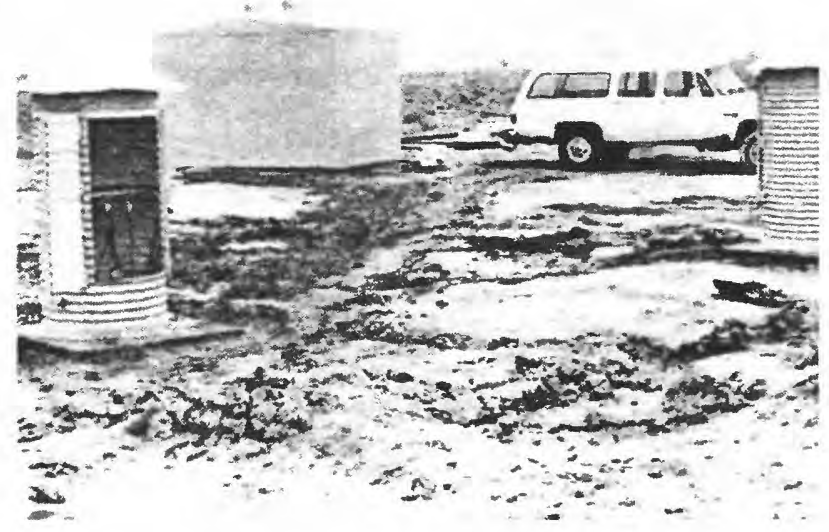

Figure 9. Holly extensometer site, looking east. Extensometer is in large building in center. Observation wells are in small, round buildings. Landsurface elevation is 2,302 feet. Photographed August 1990.

\section{EXTENSOMETER INMTALLATION}

In May 1990, an extensometer was installed at the Holly well site (fig. 9) to measure the amount and rate of land subsidence near the South Track well field (fig. 5). This site was selected because bench marks M1155 and P1155, near the extensometer site, have subsided more than $3 \mathrm{ft}$ since 1961 and represent the largest amount of subsidence documented to date on the base (fig. 6).

At the extensometer site, an $8-\times 12$-foot metal building houses the extensometer, and two small, round 36-inch diameter buildings (fig. 9) house the

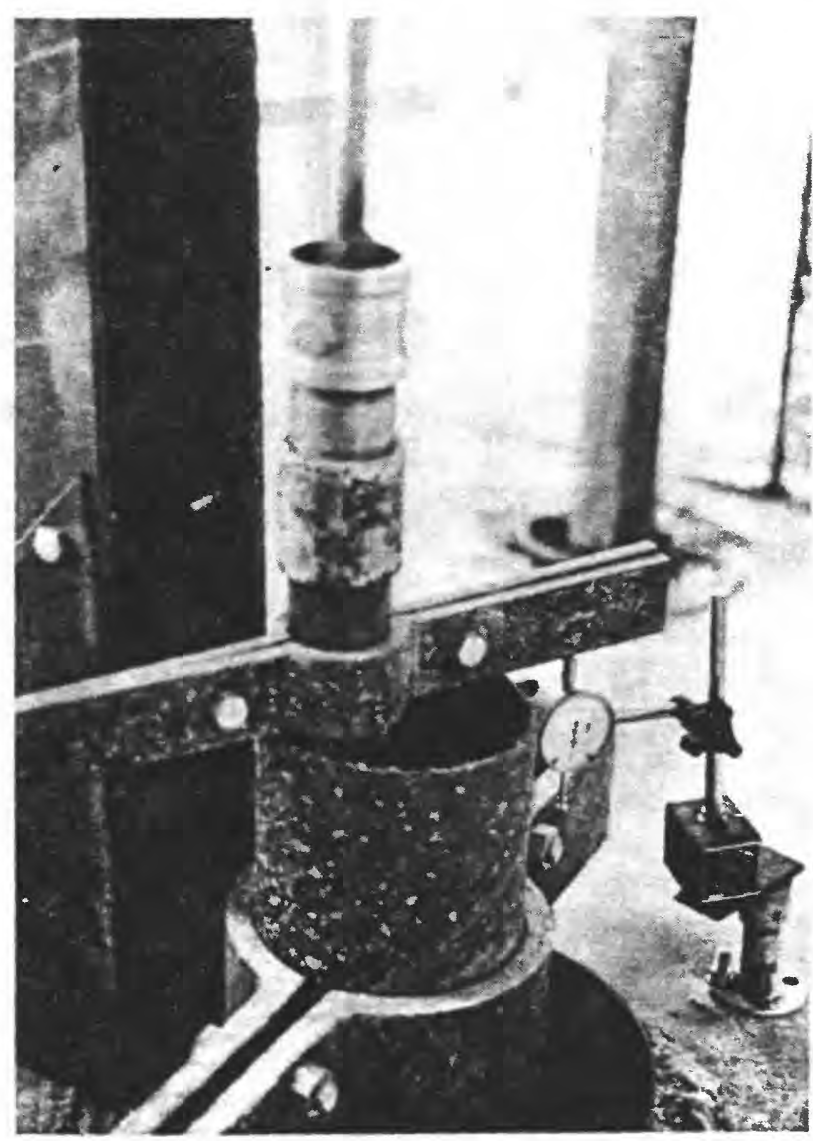

Figure 10. Holly extensometer. A 2-inch diameter pipe in center extends to a concrete anchor 840 feet below land surface. Dial indicator on right measures difference in distance between concrete floor (land surface) and horizontal bracket on pipe. Photographed May 1990. 
nested observation wells that are used to measure water levels. The extensometer is a 10 -inch diameter steel casing placed at land surface to protect a 6 -inch diameter steel well casing that is $810 \mathrm{ft}$ deep. Inside the 6-inch diameter casing and extending below land surface is a 2-inch diameter steel pipe embedded in concrete at a depth of about $840 \mathrm{ft}$. Granitic rock (possibly bedrock) at this site was $1,097 \mathrm{ft}$ below land surface. The concrete anchor for the 2-inch diameter pipe is normally placed on bedrock or in coarsegrained strata several hundred feet below the level of ground-water pumping or strata that may be subject to subsidence. As the land surface subsides, the 2inch diameter pipe will extend further above the land surface, and the amount and rate of land subsidence are then recorded using a data logger, drum recorder, and dial indicator (fig. 10).
Aquifer compaction at the Holly extensometer site between May 11, 1990, and October 1, 1991, was $0.078 \mathrm{ft}$ (fig. 11). The rates of compaction shown on this figure, $1.88 \times 10^{-4} \mathrm{ft} / \mathrm{d}$ prior to Julian day 259 (September 17, 1990), and $1.97 \times 10^{-4} \mathrm{ft} / \mathrm{d}$ after Julian day 463 (April 12, 1991), indicate a continued rate of aquifer compaction that decreased only during the winter months of October 1990 through April 1991.

Water levels were measured at four wells located in two buildings near the Holly extensometer (fig. 9). One building houses one 2-inch diameter pipe placed to a $130 \mathrm{ft}$ depth and two wells with 3-inch diameter pipes placed to depths of 470 and $645 \mathrm{ft}$. The second building houses a well that is $1,020 \mathrm{ft}$ deep. Water

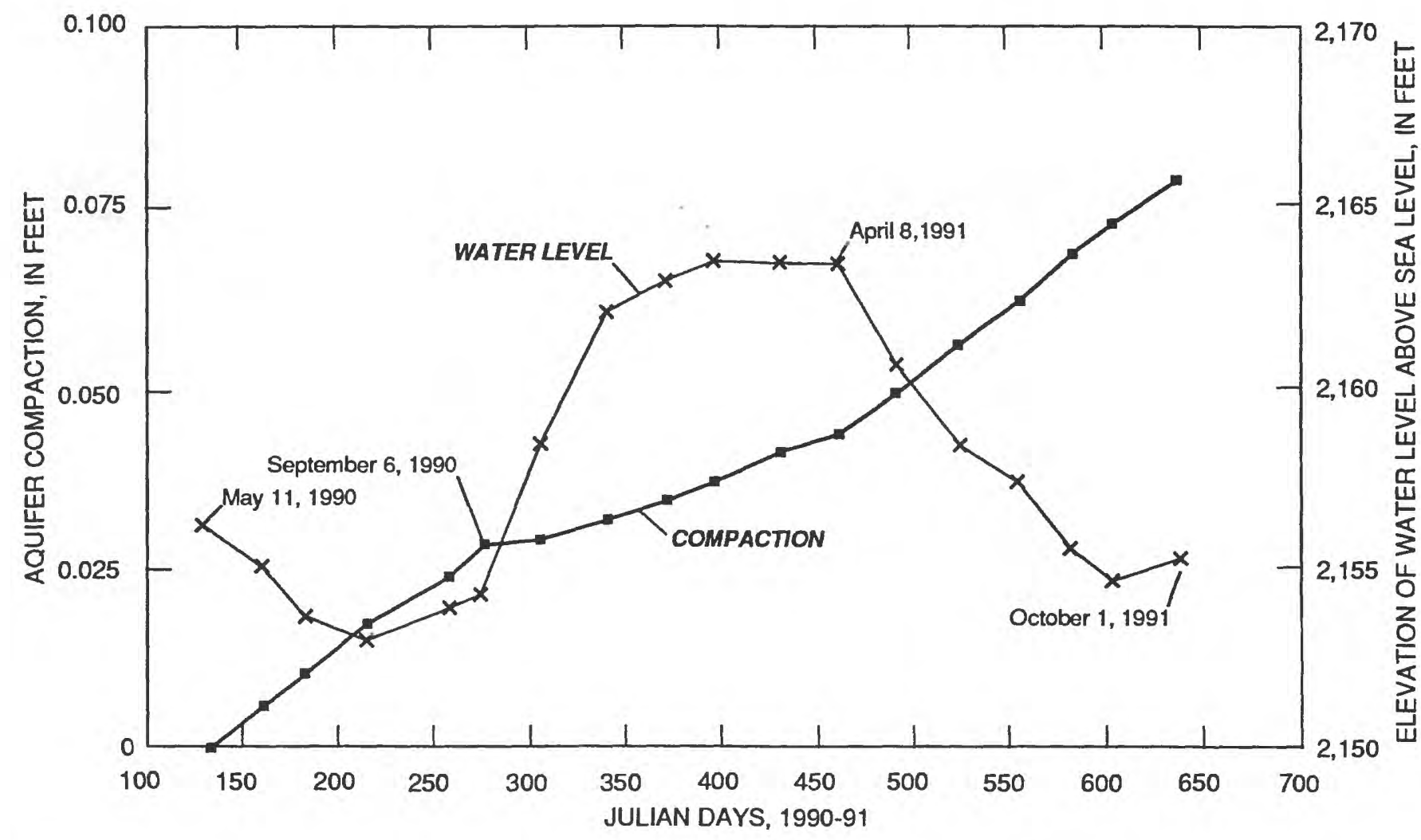

Figure 11. Aquifer compaction and water-level change between May 1990 and October 1991 at the Holly extensometer site. 
levels in the wells are measured continuously, and the data are recorded on a data logger located in the extensometer building. The period during which subsidence occurs at a reduced rate corresponds to the winter and spring months, September 1990 to April 1991 (fig. 11) when water levels at the site stabilized or rose; this period of stability is attributed to reduced pumping from the South Track well field during the winter months.

\section{LAND-SURFACE PROFILES}

Areal variation of land subsidence at Edwards AFB is shown by changes in surface profiles of transects $A, B$, and $C$ (fig. 12). Transect $A$ is oriented north-south; transect B is oriented east-west. Transect $C$ is on Rogers Lake; bench marks for this transect are located off the lake so calculations of changes of the lakebed elevation are estimates.

Transects A and B (figs. 13 and 14) show that the area of greatest subsidence is near the southern part of the base. Land subsidence along transect A occurs north of Hospital Road between bench marks E1140 and G1140, and south of Hospital Road between bench marks G1155 and 106-116 (fig. 12). The presence of two subsidence areas bordering Hospital Road indicates that this low ridge may act as a separation between land-surface deformation to the north and south. Transect $\mathrm{A}$ also shows that subsidence along the western edge of Rogers Lake extends about $8 \mathrm{mi}$ south of Hospital Road. The pattern of land subsidence on transects A and B (figs. 13 and 14) shows that land subsidence probably occurred at the south end of Rogers Lake. Subsidence is apparent along all of transect B (figs. 12 and 14) as indicated by changes in elevation between bench mark N487, which is near Sierra Highway, and bench mark 3MDC.

A profile of transect $\mathrm{C}$ on Rogers lakebed is shown in figure 15 . The lowest point shown on this profile, elevation $2,267.8 \mathrm{ft}$, is about $11,000 \mathrm{ft}$ north of bench mark 4RLB. The elevation of the lakebed near this low point may show the effects of land subsidence, because nearby bench marks along the south edge of Rogers lakebed J1155, K1155, L1155, M1155, and N1155 (fig. 6) all show 1 or more feet of land subsidence during 1961-91 (table 2). Because about $3 \mathrm{ft}$ of lakebed subsidence occurred near bench marks M1155 and L1155 at the south end of the lakebed and $0.2 \mathrm{ft}$ near bench mark R1140 at the north end (fig. 6), the slope of the entire lakebed probably is affected by various amounts of change in slope, with the southern part the most affected. Any change in lakebed slope represents an increase in the potential for lakebed erosion caused by wind-induced movement of water during periods of lakebed flooding. Increases in lakebed slope typically result in greater hydraulic shear stresses and increased erosion during periods of lakebed flooding that causes greater lengths and densities of existing drainage channels (number of channels in a given area) and formation of new drainage channels, which collectively are called desert flowers (fig. 16).

\section{RATES OF LAND SUBSIDENCE}

Estimates of land-subsidence rates are best obtained from a comparison of elevations measured at one bench mark for a period of years. The relative stability of bench marks can be identified by comparing repeated, adjusted elevations; those showing little change are considered to be more stable. Differences in measured elevation of bench marks less than about $0.2 \mathrm{ft}$ are not considered reliable indications of land subsidence (Blodgett and others, 1990).

Land subsidence of 3.2 and $3.3 \mathrm{ft}$ at bench marks M1155 and P1155, respectively (fig. 6), near the South Track well field are the maximum determined on the base to date and were determined by comparing surveys made in 1961 and 1989 (table 1). Bench mark F1147 near Rosamond was used as the stable reference for all surveys.

The average rate of land subsidence at bench mark M1155 was $0.109 \mathrm{ft} / \mathrm{yr}$ between 1961-89 (fig. 17). The average rates of land subsidence at most other bench marks in the study are less than that of bench mark M1155 (fig. 6). Variation in these subsidence rates is related to the variable effects of ground-water pumping at different locations on the base and lithologic variation in the substrata. 


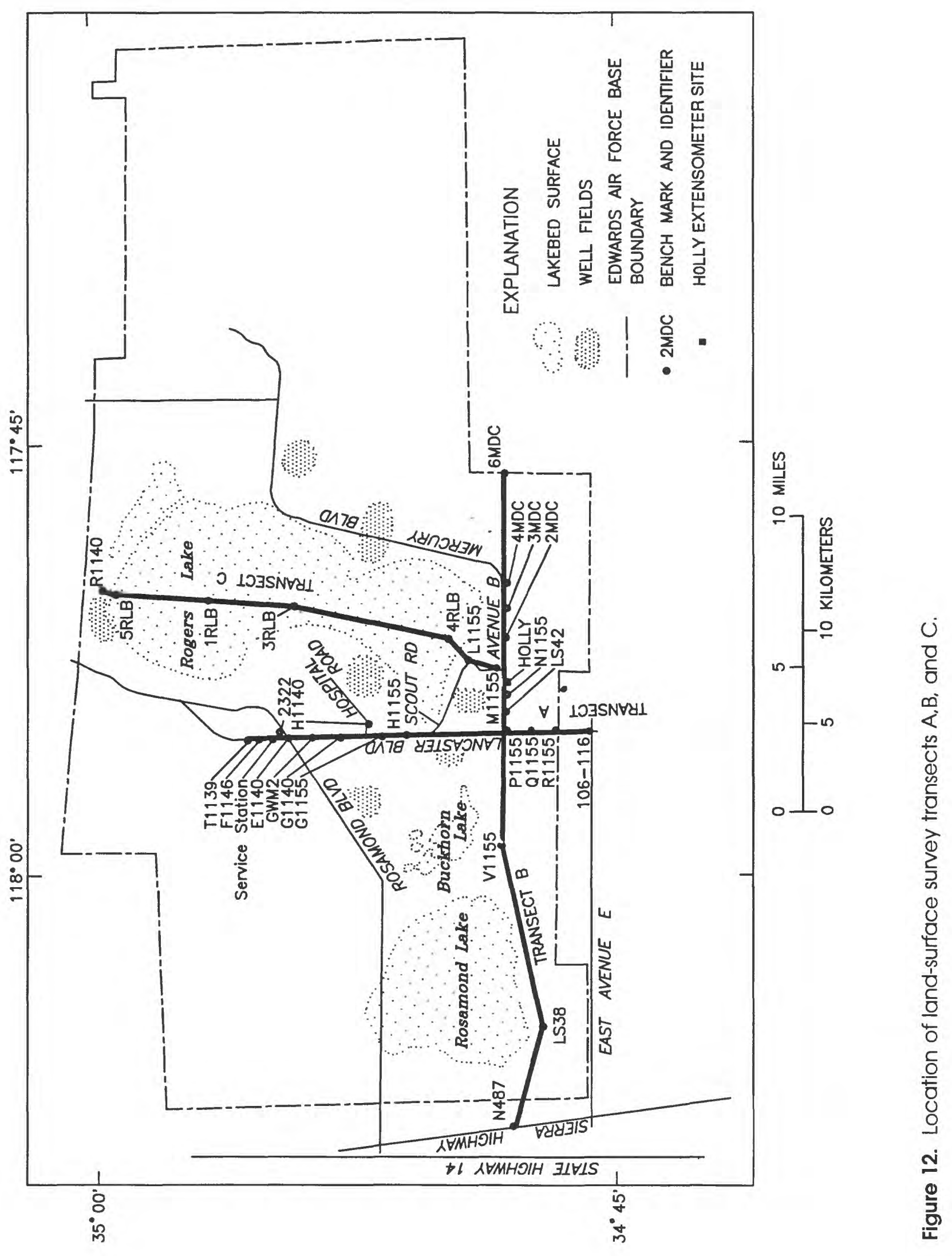




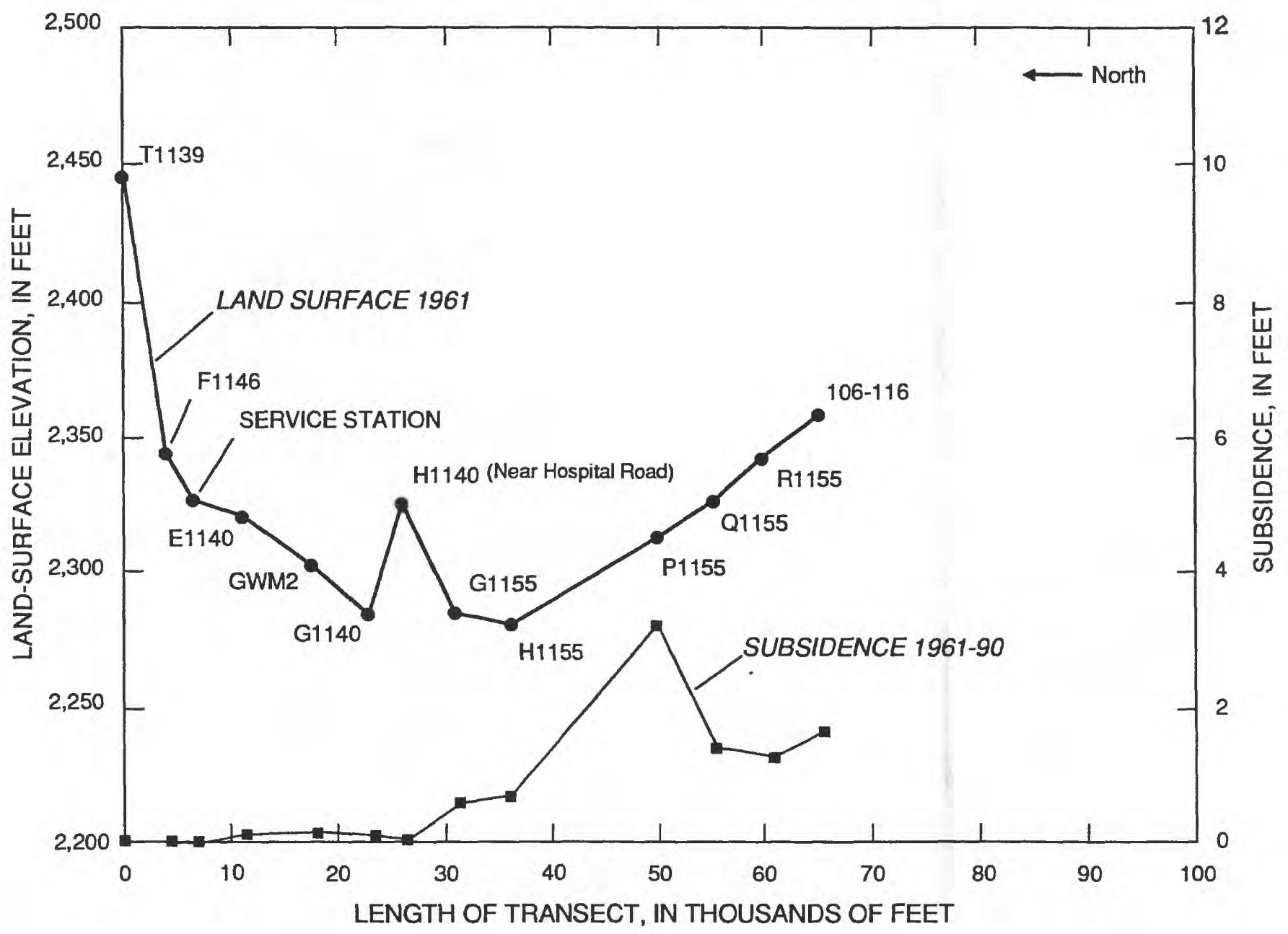

Figure 13. Land-surface elevation, transect A, Lancaster Boulevard.

\section{LAND SUBSIDENCE AND ASSOCIATED PROBLEMS AFFECTING LAND USE}

Land subsidence caused by ground-water pumping is a progressive phenomenon that occurs during a period of years. Several well fields are located along the margins of Rogers Lake (fig. 5). The amount and areal extent of land subsidence and associated land-use problems on Rogers lakebed are related to the lowering of ground-water levels and lithologic variations in the substrata. The effect of land subsidence on certain land-use practices may not be a cause for concern. In other instances, however, such as increased urbanization, the effects of land subsidence may be significant. Several land-use problems, caused by continuing land subsidence at Edwards AFB, have been noted. These include

- Failure of well casings caused by compression stresses developed during compaction of the aquifer system.

- Damage to fluid-transport systems, such as underground water, sewer, and petroleum lines. 


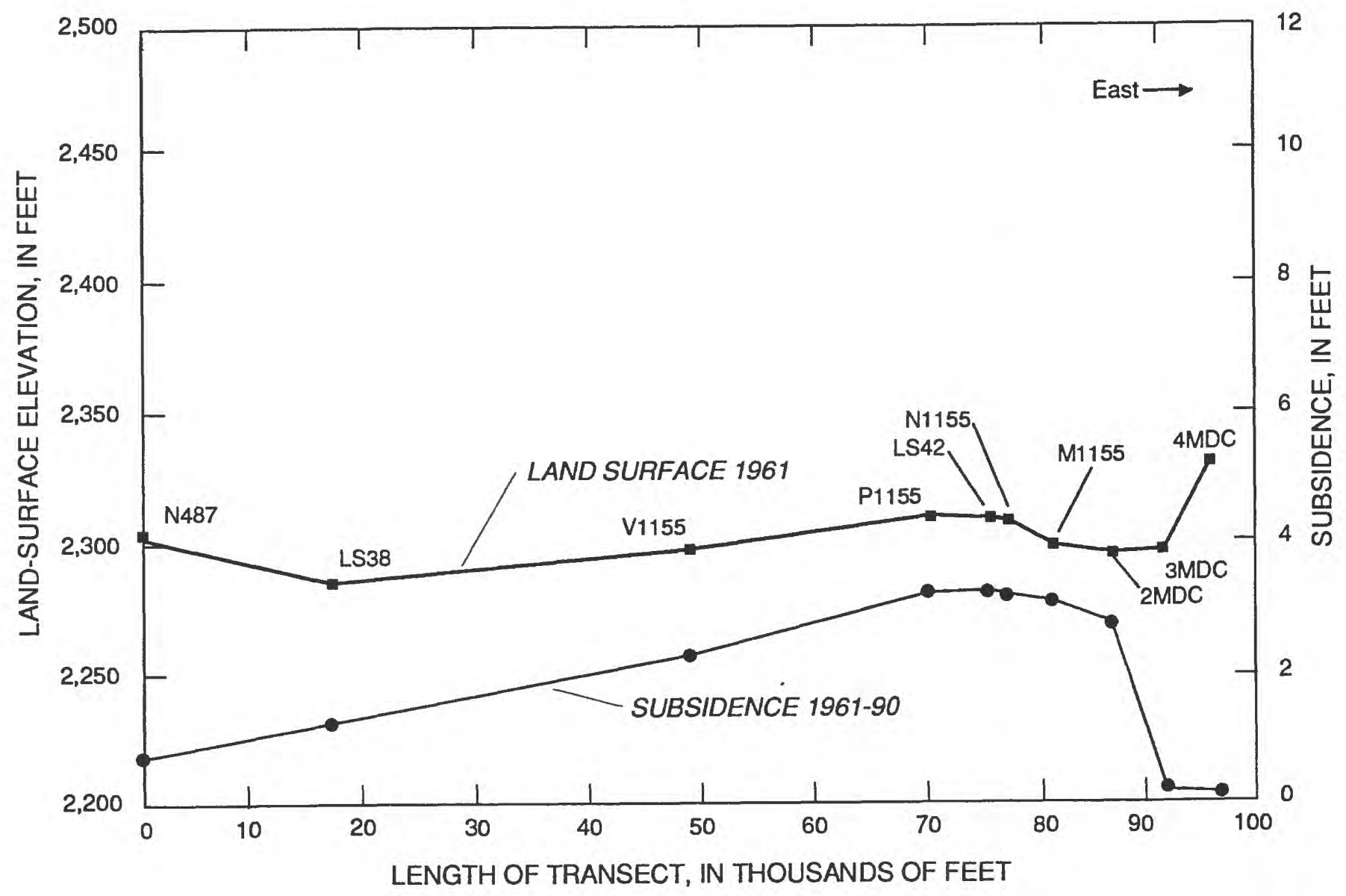

Figure 14. Land-surface elevation, transect B, Avenue B.

- Erosion of drainage channels and formation of new drainage channels (waterways) on the lakebed caused by changes in elevation and gradient of the lakebed and wind-induced movement of the ponded water (fig. 16).

- Increase in areas subject to flooding as a result of land subsidence.

- Development of cracks, fissures, sinklike depressions, and soft spots (loss of load-bearing capacity) on the lakebed that affect the use of runways.
- Rapid drainage of water on the lakebed into fissures and sinklike depressions. The Air Force has observed that during lakebed flooding in 1983 much of the water on the lakebed drained into fissures and sinklike depressions within 24 hours of 1 inch of precipitation (Phillip Brady, U.S. Air Force, written commun., 1991). Water on the lakebed contains suspended sediment that is scoured from the beds and banks of channels tributary to Rogers Lake. In addition, water on the lakebed contains suspended sediment caused by lakebed erosion when the water mass is moved by the wind. Inflow of the lakebed water into 


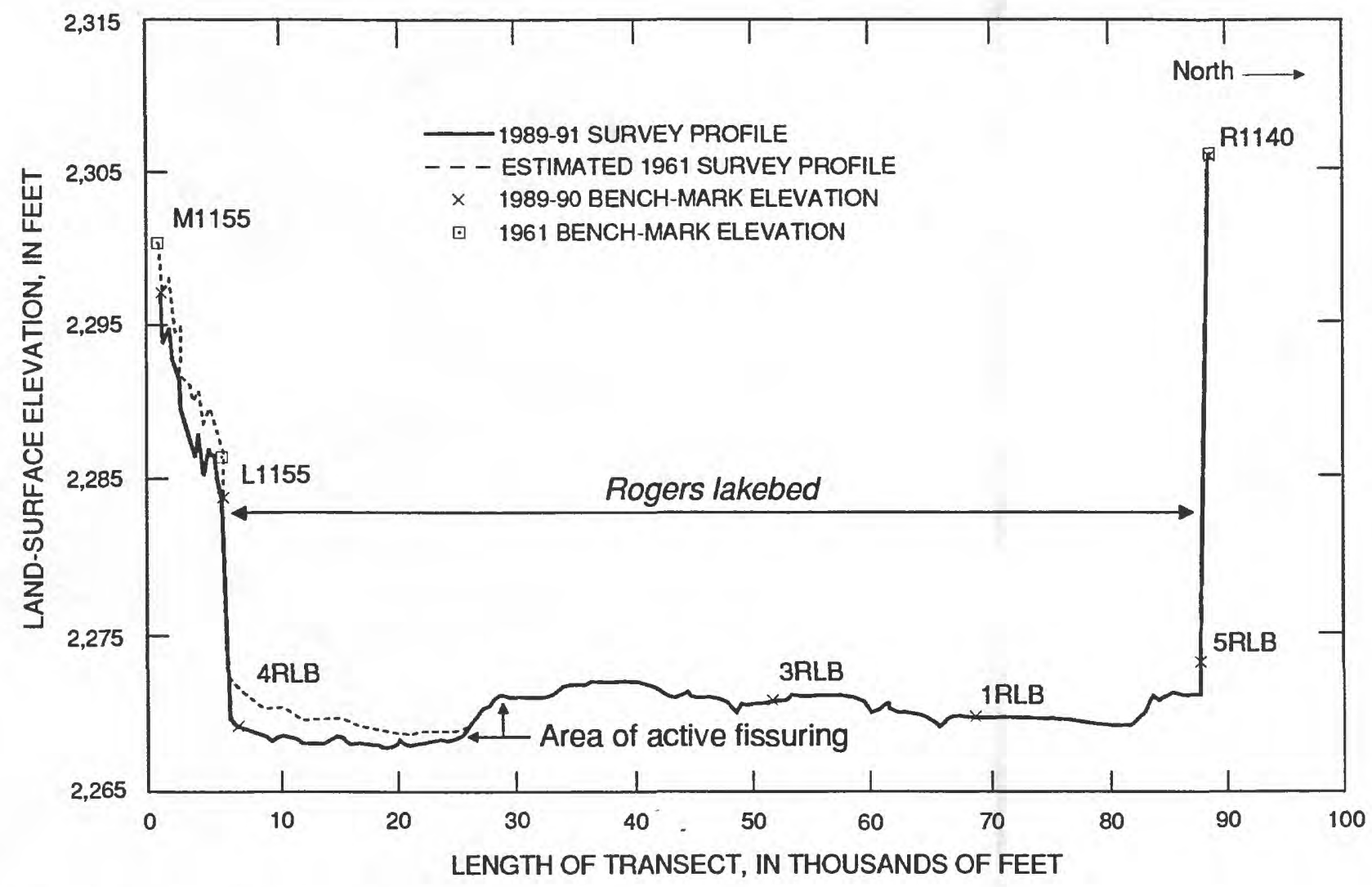

Figure 15. Land-surface elevation, transect $C$, Rogers lakebed.

fissures and sinklike depressions tends therefore to reduce the quantity of water that is moved by wind on the lakebed and is available to fill surface irregularities by deposition on the lakebed. Formation of gullies and channels along the sides of the fissures is an additional detrimental effect caused by drainage of surface water (fig. 18). Erosion during subsequent periods of lakebed flooding cause these gullies and channels to enlarge and deepen. Slumping (shear failure), erosion along the sides of the fissures, and, as reported by Schumann and others (1986), rapid piping along the strike of the fissure also cause the fissures to enlarge during periods of flooding.

\section{FISSURING}

The geology, mineralogy, and hydrology of selected dry lakebeds (playas) in the Western United States have been studied by numerous investigators (Neal, 1965, 1968; Motts and Carpenter, 1970), but the characteristics of these lakebeds are not well understood. Playa surfaces, which are large, flat expanses of desert, are valued for their use as long runways when testing aircraft and for use as emergency landing sites. Dry lakebeds within closed valley basins are geologically unique because the inflow consists of surface and ground water, with no surface outlet and, therefore, the lakebeds are areas of deposition for all suspended sediments and chemical constituents of the water. 


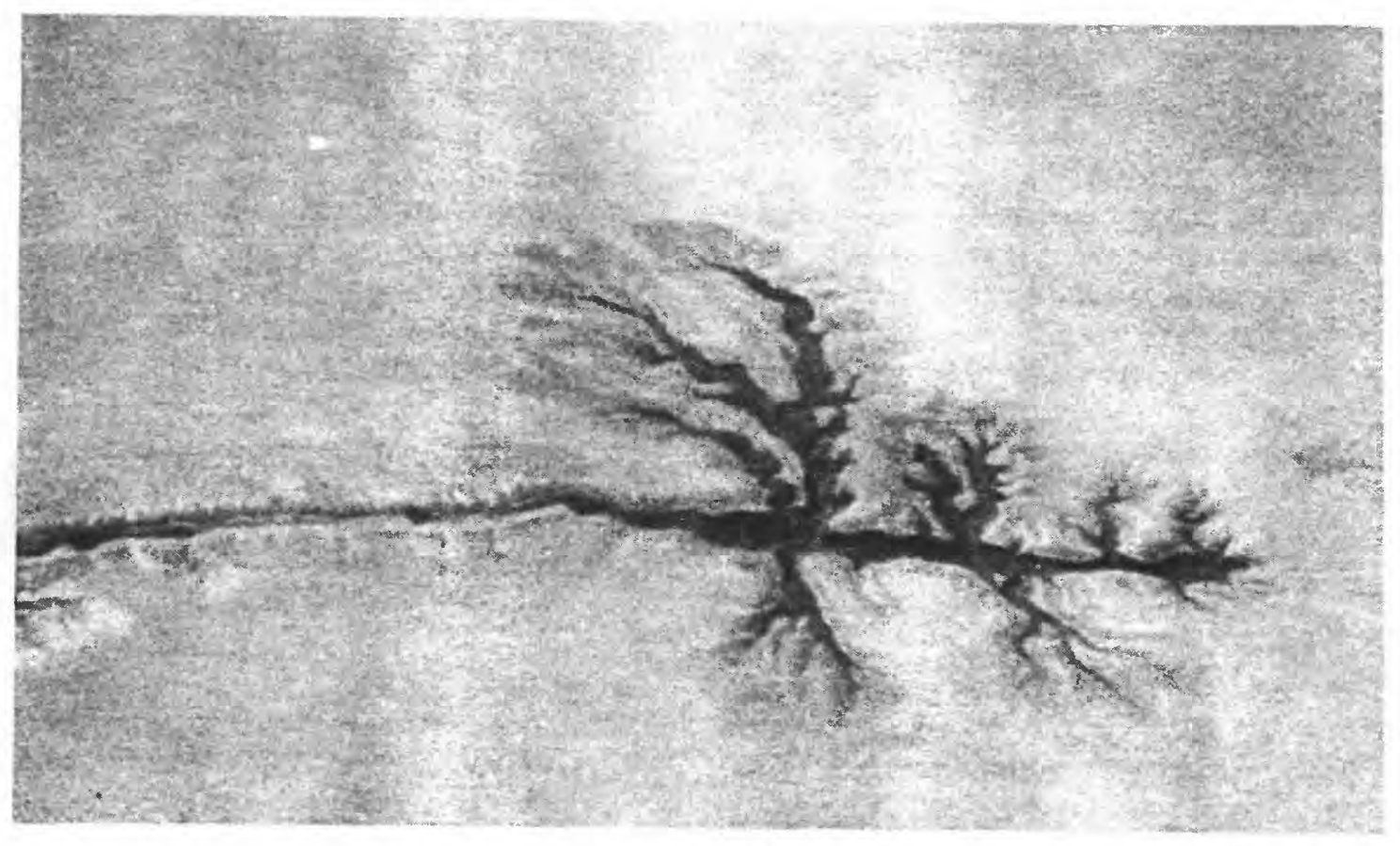

Figure 16. Drainage channels (collectively called desert flowers) caused by erosion during flooding of Rogers lakebed. Photographed August 1989.

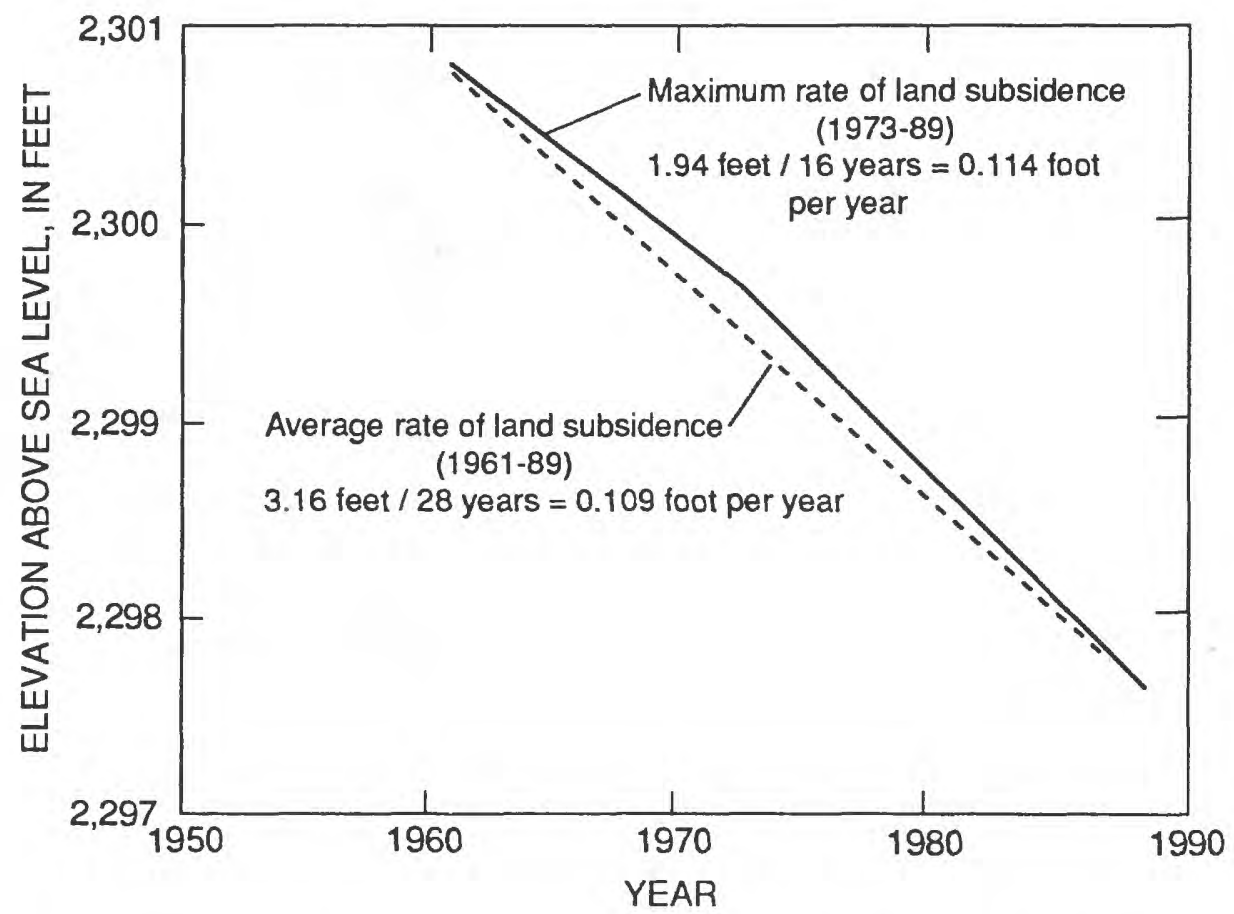

Figure 17. Land subsidence at bench mark M1 155 near South Track well field, 1967-89. 


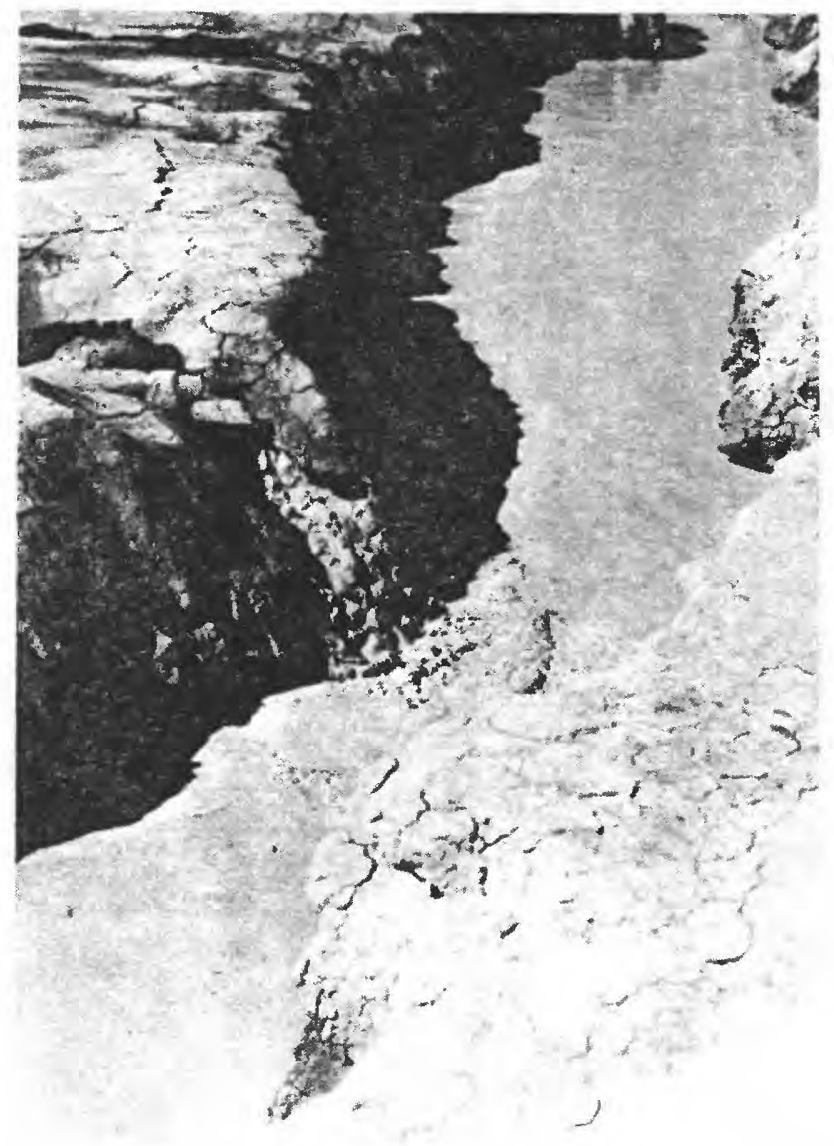

Figure 18. Erosion of Rogers lakebed caused by movement of ponded water to fissure opening, March 1991.

Dry lakebeds usually have smooth, hard, flat surfaces. Some have small (cobblestone size) polygons or large (giant) desiccation polygons (figs. 19 and 20). The small polygons range from 1 to 4 inches across; the giant polygons may exceed $300 \mathrm{ft}$ (Neal, 1965).

Giant desiccation polygons are formed by the orthogonal intersection of giant mud cracks, which commonly are as much as $3 \mathrm{ft}$ wide and $3 \mathrm{ft}$ deep (Neal, 1965). Orthogonal polygons result from volume change in a uniform horizontal mass with one surface exposed (Neal, 1968). These features are described as giant polygons to distinguish them from

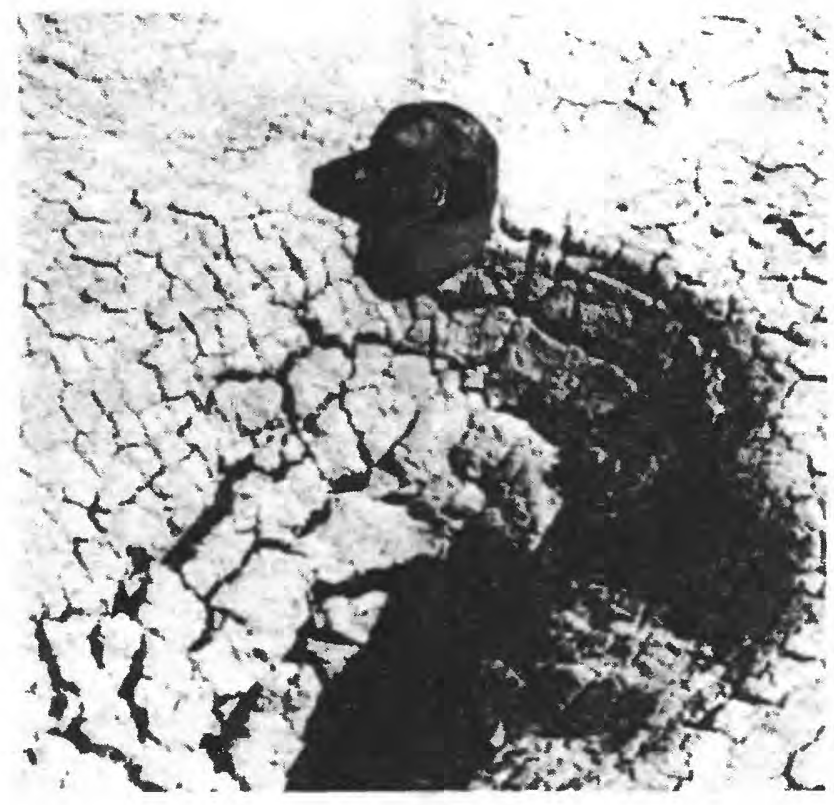

Figure 19. Small sinklike depression on Rogers lakebed showing small (cobblestone size) flat, sun-baked polygons on depression wall. The polygons are formed during moisture loss by evaporation. Photographed August 1988.

small polygons, which have shallow, surface cracks. Giant polygons on dry lakebeds evidently are caused by three factors: (1) intense evaporation at and below the land surface, (2) lowered ground-water levels, and (3) changes in size or location of polygons following precipitation. The surface features of fissures, which are caused by land subsidence and appear as large cracks on the soil surface, can be more than $9 \mathrm{mi}$ long (Schumann and others, 1986). Because of the location and size of the various types of fissures found on the lakebed, repairs often must be made to the lakebed to keep the runways operable.

The relation of surface deformation and land subsidence caused by ground-water pumping was noted previously (Feth, 1961; Poland, 1984, p. 6-7). Excessive ground-water pumping and depletion of the aquifer can cause compaction of the unconsolidated alluvium resulting in surface deformation and fissuring, as has been noted in Antelope Valley. 


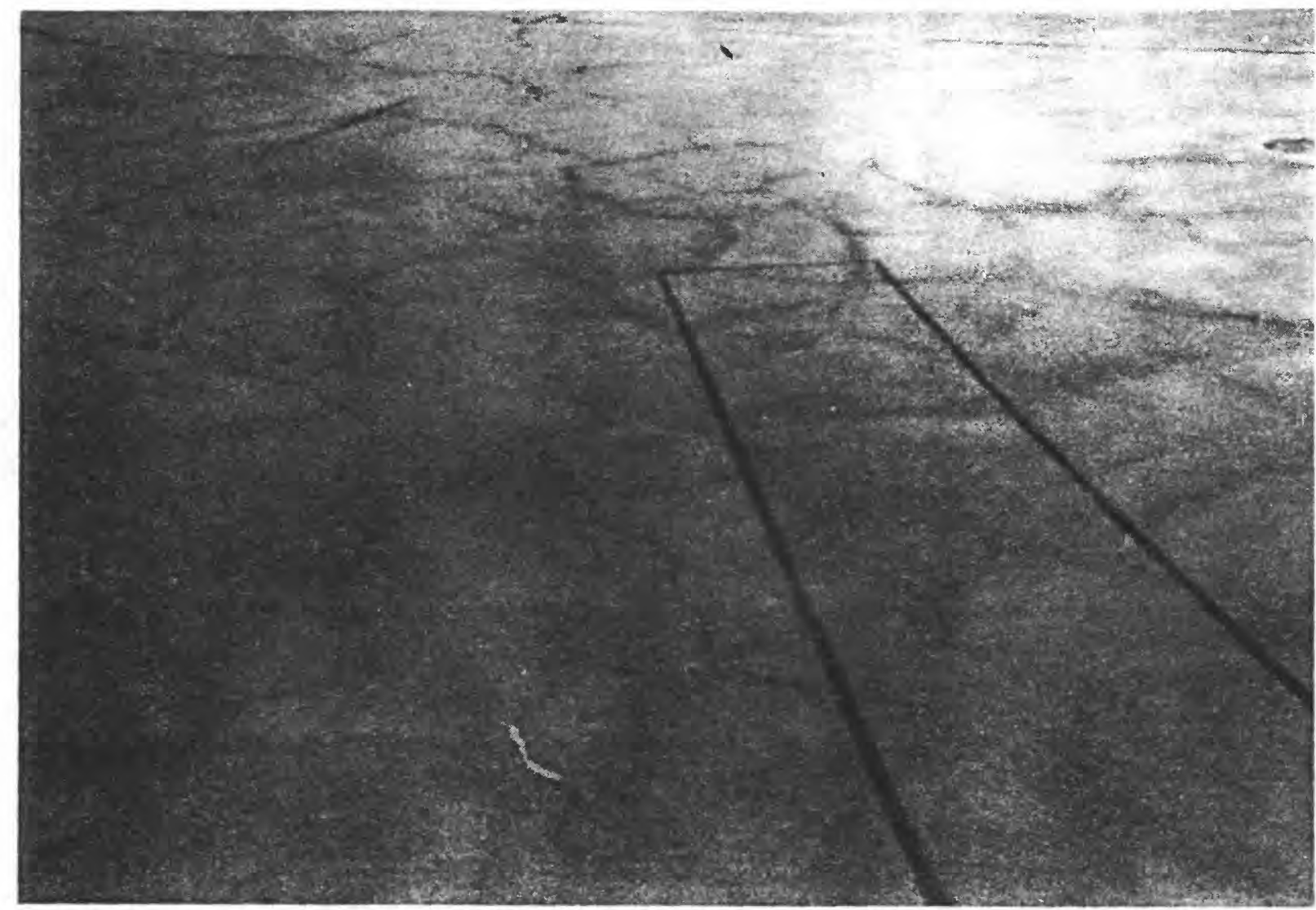

Figure 20. Aerial view of Rogers lakebed showing giant desiccation polygon cracks. Width of runway is about 330 feet. Photograph courtesy of U.S. Department of the Air Force, 1983.

Because fissures may extend to the water table, there is potential for direct surface-water access to the aquifer and possible contamination by toxic materials.

Factors that are associated with earth fissures and surface faults induced by ground-water depletion, as noted at Edwards AFB, include the following:

- Fissures generally form in a zone of tensile stress that extends to the water table. However, seismic refraction techniques have measured fissures deeper than the water table at Rogers lakebed (Neal and others, 1968). Fissure cracks may show only as a hairline crack on the land surface.
- The location of fissures may be affected by the location of subsurface bedrock or consolidated alluvium ridges that act as hinge points for deformation of the land surface. Fissures generally form in the alluvium near the edges of the areas subject to ground-water depletion (Schumann and others, 1986).

- Fissures generally occur near the part of the subsidence profile where the land surface has the greatest convex curvature upward. This phenomenon has been observed on Rogers lakebed (fig. 21).

- Fissures tend to intersect and form linear fissure systems. 


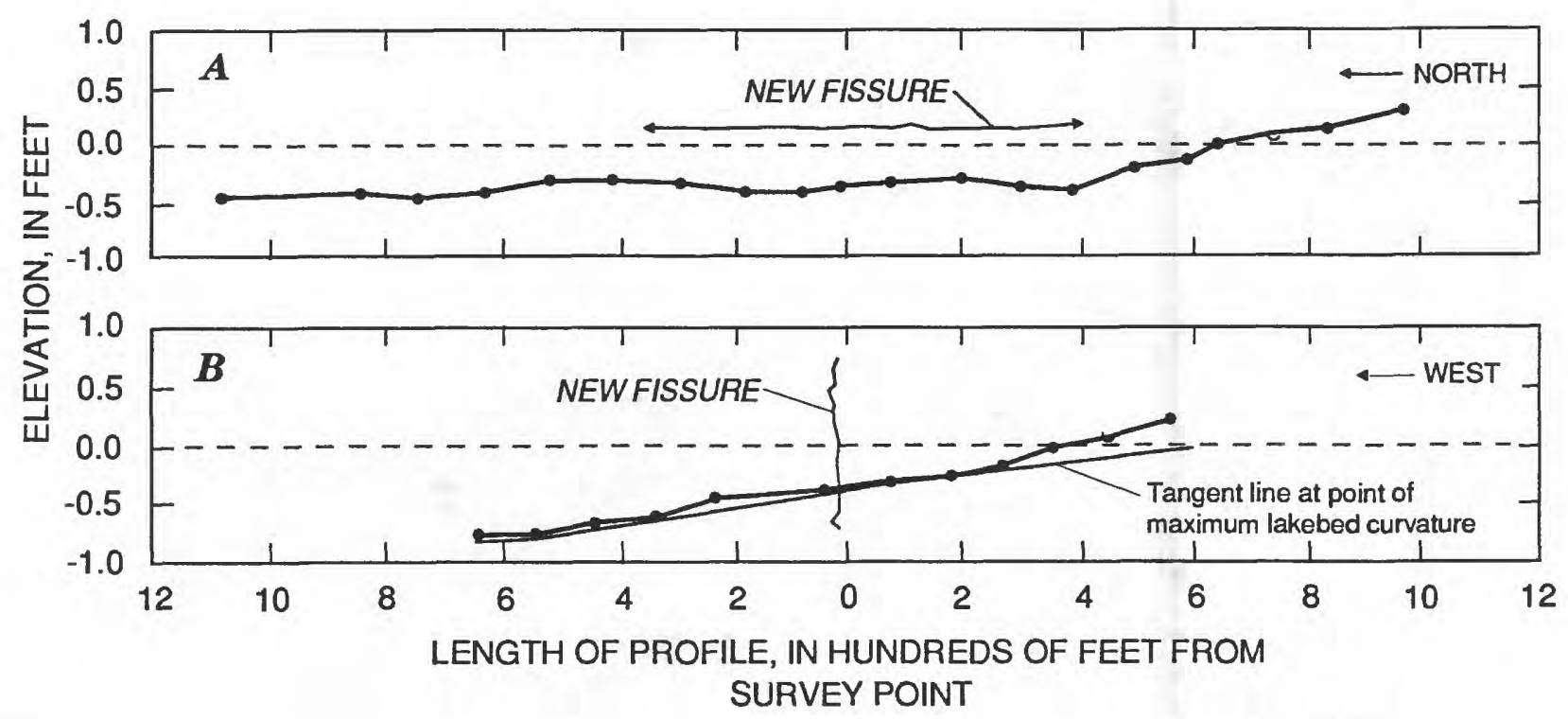

Figure 21. Land-surface profile at new fissure on Rogers lakebed. A, Longitudinal profile of land surface parallel to fissure. B, Cross profile of land surface at survey point.

- Fissures may first appear as narrow cracks (less than $0.1 \mathrm{ft}$ wide) or as an alignment of shallow holes or sinklike depressions.

- New fissures have nearly vertical sides and exhibit no evidence of lateral or vertical offset.

- Fissures form on the periphery of the area of subsidence and transect natural drainage patterns. Many capture large volumes of surface runoff. The fissures then enlarge by slumping, eroding, or piping along the strike of the fissure.

Fissures on the lakebed that were large enough to be of concern to Air Force operations were first noted about 1988. Fissures that formed prior to 1988 were obliterated when the lakebed flooded, such as in March 1983. More recently, however, new and larger fissures on the lakebed have been noted by Air Force personnel with increasing frequency. This apparent increase in the rate of fissure formation may be caused by increased ground-water pumping related to drought conditions in the area during 1984-91. In January 1991, following a period of lakebed flooding, the largest fissure observed to date was discovered on the lakebed (figs. 2 and 5). This fissure is greater than $12 \mathrm{ft}$ in depth and acts as a vertical conduit to the subsurface for water ponded on the lakebed.

\section{SINKLIKE DEPRESSIONS}

Sinklike depressions on the land surface that range in size from $0.5 \mathrm{ft}$ to several feet in diameter and from a few inches to $6 \mathrm{ft}$ in depth (figs. 22 and 23) have been found at several Edwards AFB locations. Sinklike depressions were defined by H.H. Schumann (U.S. Geological Survey, written commun., 1991), who noted a series of holes and depressions in association with earth fissures in southern Arizona. Some of the depressions have nearly vertical sides and form along trends of earth fissures that may not yet be expressed at the land surface. Sinklike depressions observed by Schumann are similar to the localized holes and depressions observed at Edwards AFB (figs. 19 and 22), with underground voids enlarged as a result of vertical and lateral movement of water or piping. The definition of these sinklike depressions differs from that for sinkholes given by Bates and Jackson $(1984$, p. 470), in which a sinkhole is a "circular depression in a karst area. Its drainage is subterranean, its size measured in meters or tens of meters, and it is commonly funnel-shaped." For sinkholes and sinklike depressions, the physical process of vertical erosion during movement of surface water into an underground void is believed to be similar. The distinction is that the definition of sinkholes applies to karst (limestone) areas, whereas sinklike depressions occur in other areas. 


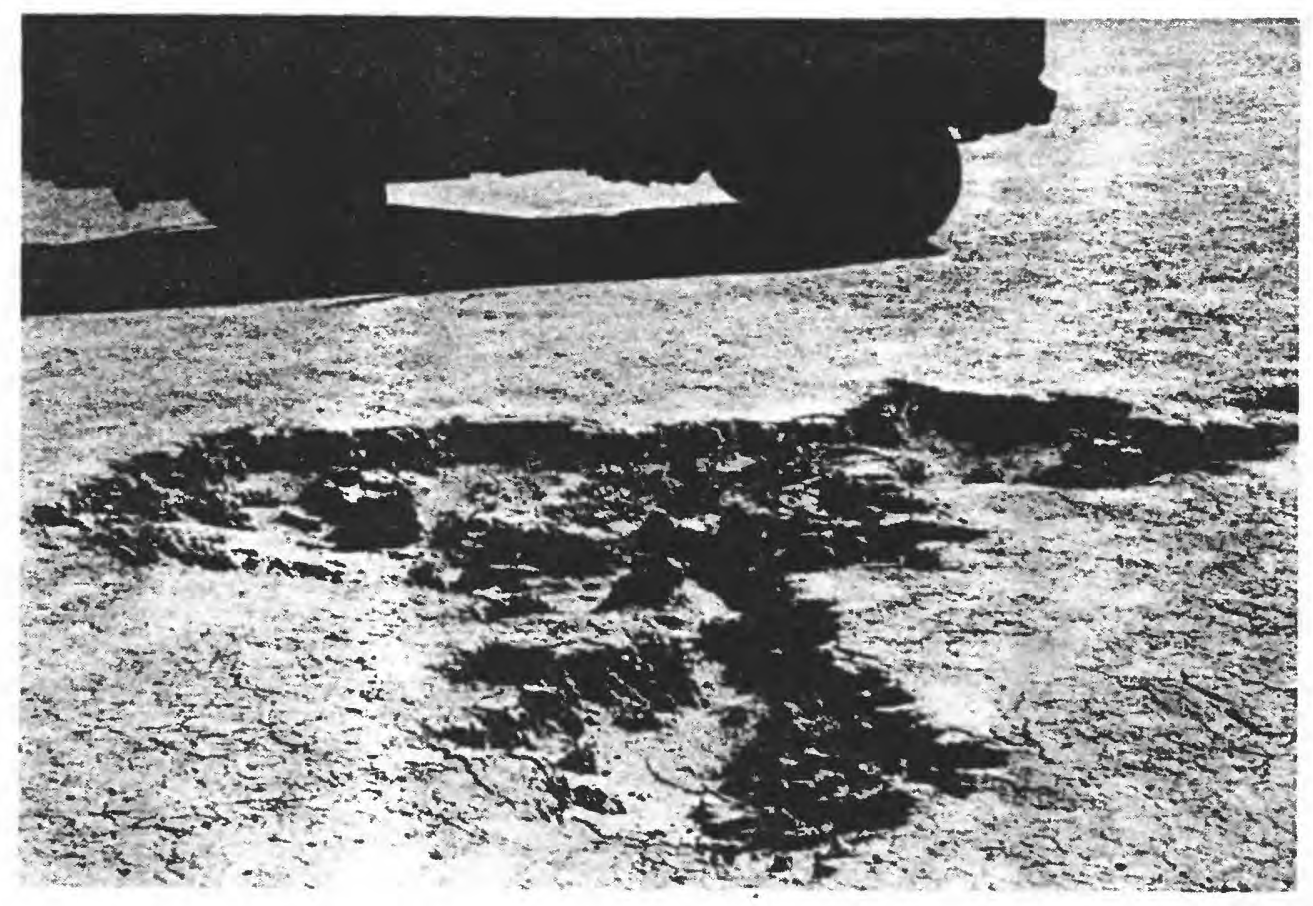

Figure 22. Expanding sinklike depression on Rogers lakebed caused by erosion during periods of lakebed flooding. Photographed June 1990.

The occurrence of sinklike depressions at Edwards AFB (fig. 22) is related to land subsidence, declining ground-water levels, and formation of giant polygons. Because all these elements are present, enlargement of older sinklike depressions and formation of new depressions are considered progressive. The rate at which new sinklike depressions form is dependent on many factors, including lakebed flooding from precipitation on the lakebed, inflow from tributaries to the lake, movement of bodies of surface water on the lakebed, and ground-water pumping that, in turn, affects the rate of subsurface (aquifer) water-level decline.

\section{LAKEBED EROSION}

Rogers lakebed is virtually flat, with a change in elevation from the north to south of only $5 \mathrm{ft}$ in a distance of $11 \mathrm{mi}$. During periods of lakebed flooding, as in March 1983 and March 1984, drainage channels formed by erosion on the lakebed (fig. 23). These channels are affected by variable amounts of inflow, timing of floods, sediment transport from tributaries, force of prevailing winds that tend to move the water west to east, and local undulations of the lakebed surface.
Erosion on dry lakebeds and subsequent formation of drainage channels, collectively called desert flowers (area A on fig. 23), were first noted by Motts and Carpenter (1970). In some locations, such as Rogers lakebed, the channels forming the dendritic channel pattern adjacent to the main channel were as deep as $0.3 \mathrm{ft}$ on the lakebed surface. Erosion of channels on the lakebed generally continues after each period of flooding and now covers an extensive part of the lakebed (fig. 23). Many drainage channels are several feet wide and several feet deep. The development of the channels on the lakebed is affected by the slope of the lakebed and also by the presence of fissures or erosion depressions, which serve as outlets for the flow.

Continued land subsidence on Rogers lakebed will affect the slope of the lakebed (fig. 15) and development of surface channels. For example, the changing and presently steeper lakebed slope between bench marks 3 RLB and 4RLB (fig. 15), affects the geomorphic characteristics of natural drainage on the lakebed. As the slope increases, the lakebed is increasingly incised with drainage channels (figs. 16 and 23). The channel network density increases in the downstream direction, with lakebed channels larger in areas $\mathrm{A}$ and $\mathrm{B}$ than in area $\mathrm{C}$ because the 


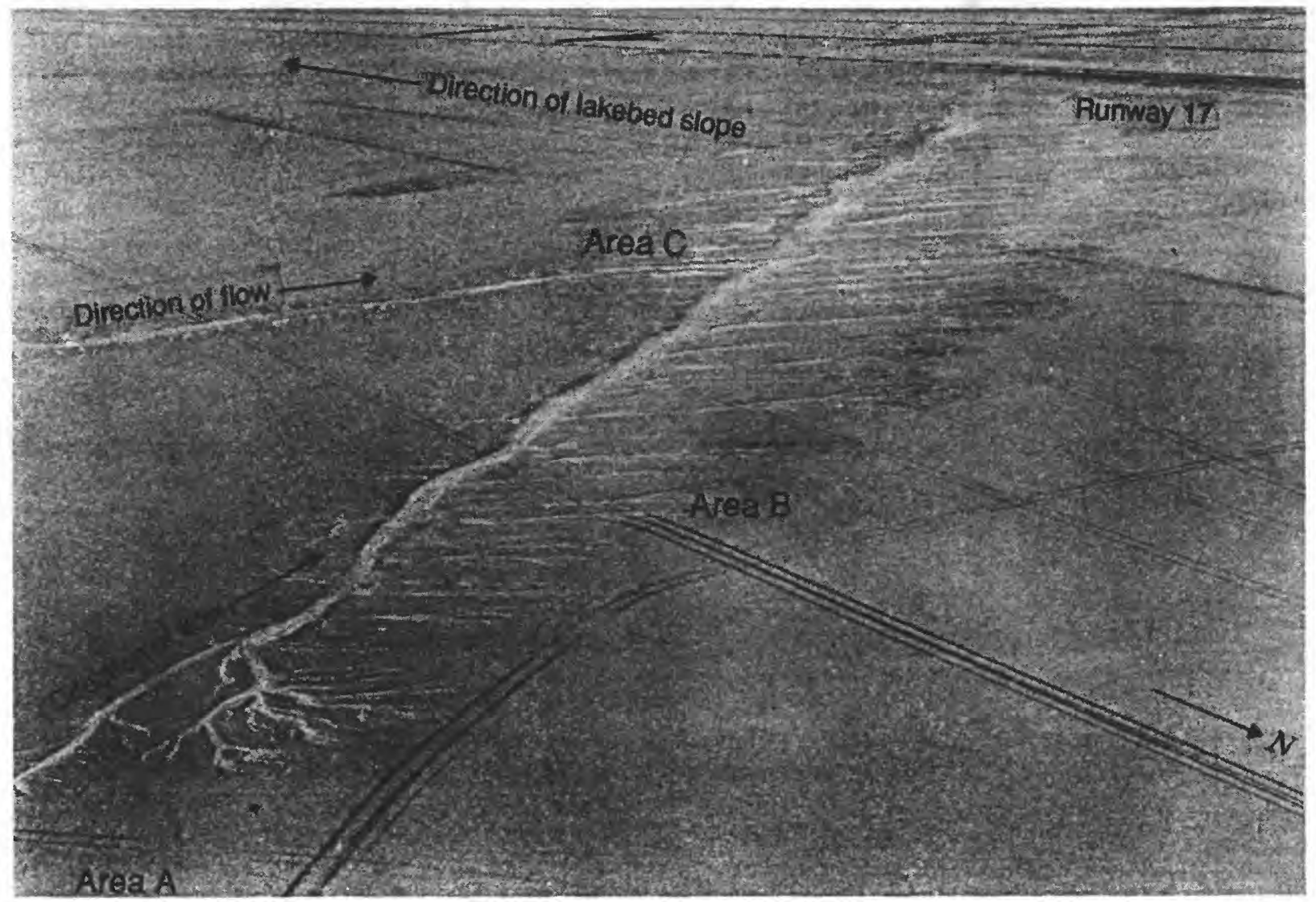

Figure 23. Oblique aerial photograph of Rogers lakebed east of South Base well field. A typical network of drainage channels (collectively call desert flowers) is shown at area A. Erosion in areas B and C is a result of land subsidence. which causes an increase in lakebed slope from north to south (right to left on photograph). Photograph courtesy of U.S. Department of the Air Force. August 1990.

lakebed slope plus channel slope is greater in areas A and $B$ than in area $C$. The length of the drainage channels is a function of the lakebed slope, with the length increasing from area $\mathrm{A}$ toward areas $\mathrm{B}$ and $\mathrm{C}$. A detrimental feature of this type of erosion and channel formation is that the presence of water on the lakebed, either from direct rainfall or flooding by tributaries, will extend the channel erosion and sediment transport processes toward low points on the lakebed.

\section{SUMMARY}

To document current land subsidence at Edwards Air Force Base and vicinity, a vertical-control network with 41 bench marks was surveyed using the Global Positioning System (GPS). Four bench marks that were unaffected by subsidence and with known geoidal heights were used in adjusting the GPS surveys to sea-level datum. Accuracy of the ellipsoidal height for the surveyed area, based on North American Datum 1983 and relative to sea level, is about 0.1 foot. Differential levels to third-order standards of accuracy were surveyed for 65 bench marks in 1989-91 to determine the areal distribution of subsidence. Measured land subsidence ranged from 3.3 feet along the southern edge of Edwards Air Force Base to about 0.3 foot on the northern edge. Near the southern edge of Rogers lakebed, the land has subsided more than 2 feet between 1961 and 1989. The average rate of land subsidence near the south end of Rogers lakebed is about 0.1 foot per year. A gradual decline of ground-water levels, more than 90 feet at some wells since 1947, is associated with the land subsidence. 
The formation of fissures and sinklike depressions and the formation of drainage channels, which are caused by erosion of Rogers lakebed during periods of flooding, also are associated with the occurrence of land subsidence. The development of fissures on the lakebed are a major concern because they may extend to the water table, allowing direct access for contamination by toxic materials. In addition, existing sinklike depressions, fissures, and cracks may not be detected until the load capacity of the overlying soil is unexpectedly exceeded when aircraft or space shuttles land or take off from the lakebed. Changes in lakebed slope and continued land subsidence contribute to the formation of new drainage channels on the lakebed. These channels, which increase in size and density following periods of precipitation or lakebed flooding, often cross runways resulting in a need for extensive repairs.

\section{REFERENCES CITED}

Bates, R.L., and Jackson, J.A., 1984, Dictionary of geological terms: Garden City, New York, Anchor Press/Doubleday, $571 \mathrm{p}$.

Blodgett, J.C., Ikehara, M.E., and Williams, G.E., 1990, Monitoring land subsidence in Sacramento Valley, California, using GPS: American Society of Civil Engineers, Journal of Surveying Engineering, v. 116, no. 2, p. 112-130.

Bock, Y., Abbott, R.I., Counselman, C.C., Gourevitch, S.A., and King, R.W., 1984, Ellipsoidal height differences in a 35-station network measured by Interferometry with GPS: American Geophysical Union Chapman Conference on Vertical Crustal Motion-Measurement and Modeling, Harpers Ferry, West Virginia, October 22-26, 13 p.

Collins, James, 1989, Fundamentals of GPS baseline and height determinations: American Society of Civil Engineers, Journal of Surveying Engineering, v. 115, no. 2, p. 223-235.

Dibblee, T.W., Jr., 1958, Tertiary stratigraphic units of the western Mojave Desert, California: Bulletin of the American Association of Petroleum Geologists, v. 42, no. 1, p. 135-144.

Dibblee, T.W., Jr., 1963, Geology of the Willow Springs and Rosamond quadrangles, California: U.S. Geological Survey Bulletin 1089-C, 253 p.

Durbin, T.J., 1978, Calibration of a mathematical model of the Antelope Valley ground-water basin, California: U.S. Geological Survey Water-Supply Paper 2046, 51 p.

Feth, J.H., 1961, A new map of western conterminous United States showing the maximum known or inferred extent of Pleistocene lakes: U.S. Geological Survey Professional Paper 424-B, p. 110-112.
Holzer, T.L., 1986, Ground failure caused by groundwater withdrawal from consolidated sediments: United States, in Johnson, A.I., and others, eds., Land subsidence: International Association of Hydrological Sciences, Publication No. 151, p. 747-756.

Lewis, R.E., and Miller, R.E., 1968, Geologic and hydrologic maps of the southern part of Antelope Valley, California, supplement to U.S. Soil Conservation Service Report on the cooperative soil survey of Antelope Valley area, California: U.S. Department of Agriculture Report, 13 p.

Lofgren, B.E., 1966, Subsidence related to ground-water withdrawal, in Landslides and subsidence: California Resources Agency, Geologic Hazards Conference, 2d, Los Angeles, California, 1965, Proceedings, p. 105-110.

Motts, W.S., and Carpenter, David, 1970, Geology and hydrology of Rogers Playa and Rosamond Playa, California, in Motts, W.S., ed., Geology and hydrology of selected playas in western United States: Amherst, University of Massachusetts, Final Scientific Report Contract No. AFL 19(628)-2486, Air Force Cambridge Research Laboratories, p. 23-65.

National Oceanic and Atmospheric Administration, Federal Geodetic Control Committee, 1980, Classification, standards of accuracy, and general specifications of geodetic control surveys: U.S. Department of Commerce, $12 \mathrm{p}$.

Neal, J.T., 1965, Geology, mineralogy, and hydrology of U.S. playas: Air Force Cambridge Research Laboratories, $176 \mathrm{p}$.

Neal, J.T., ed., 1968, Playa surface morphology: miscellaneous investigations: Bedford, Massachusetts, Air Force Cambridge Research Laboratories, Environmental Research Papers, No. 283, 150 p.

Neal, J.T., Langer, A.M., and Kerr, P.F., 1968, Giant desiccation polygons of great basin playas: Geological Society of America Bulletin, v. 79, p. 69-90.

Poland, J.F., ed., 1984, Guidebook to studies of land subsidence due to ground-water withdrawal, no. 40 of UNESCO Studies and Reports in Hydrology: Paris, France, United Nations Educational, Scientific, and Cultural Organization, 305 p., 5 appendixes.

Rapp, R.H., and Cruz, J.Y., 1986, Spherical harmonic expansions of the Earth's gravitational potential to degree 360 using 30' mean anomalies: Department of Geodetic Science and Surveying, Ohio State University, Columbus, Ohio, Report No. 376.

Schumann, H.H, Cripe, L.C., and Laney, R.L., 1986, Land subsidence and earth fissures caused by groundwater depletion in southern Arizona, U.S.A., in Johnson, A.I., and others, eds., Land subsidence: International Association of Hydrological Sciences, Publication No. 151, p. 841-851.

U.S. Department of Commerce, 1966, Coast and Geodetic Survey vertical control data: Washington, D.C., 13 p. 
U.S. DEPARTMENT OF THE INTERIOR

Geological Survey, Room W-2233

2800 Cottage Way, Federal Building

Sacramento, CA 95825 